\title{
Potential for Hydrogen Production from Key Renewable Resources in the United States
}

Technical Report NREL/TP-640-41134

February 2007

A. Milbrandt and M. Mann

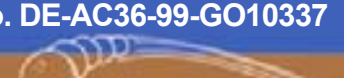




\section{Potential for Hydrogen Production from Key Renewable Resources in the United States}

Technical Report NREL/TP-640-41134

February 2007

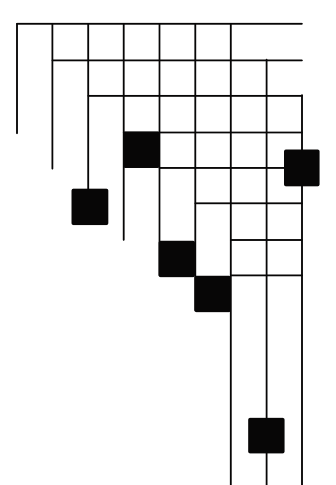




\section{NOTICE}

This report was prepared as an account of work sponsored by an agency of the United States government. Neither the United States government nor any agency thereof, nor any of their employees, makes any warranty, express or implied, or assumes any legal liability or responsibility for the accuracy, completeness, or usefulness of any information, apparatus, product, or process disclosed, or represents that its use would not infringe privately owned rights. Reference herein to any specific commercial product, process, or service by trade name, trademark, manufacturer, or otherwise does not necessarily constitute or imply its endorsement, recommendation, or favoring by the United States government or any agency thereof. The views and opinions of authors expressed herein do not necessarily state or reflect those of the United States government or any agency thereof.

Available electronically at http://www.osti.gov/bridge

Available for a processing fee to U.S. Department of Energy and its contractors, in paper, from:

U.S. Department of Energy

Office of Scientific and Technical Information

P.O. Box 62

Oak Ridge, TN 37831-0062

phone: 865.576 .8401

fax: 865.576 .5728

email: mailto:reports@adonis.osti.gov

Available for sale to the public, in paper, from:

U.S. Department of Commerce

National Technical Information Service

5285 Port Royal Road

Springfield, VA 22161

phone: 800.553.6847

fax: 703.605.6900

email: orders@ntis.fedworld.gov

online ordering: http://www.ntis.gov/ordering.htm 


\section{Acknowledgments}

The study was performed by analysts at the U.S. Department of Energy's National Renewable Energy Laboratory under contract number DE-AC36-99-GO10337. For their valuable contributions, the authors would like to acknowledge Donna Heimiller and Johanna Levene from the National Renewable Energy Laboratory. A special thanks to Fred Joseck from the U.S. Department of Energy's Hydrogen Program for his continued assistance, which made the completion of this study possible. 


\section{Executive Summary}

This study was conducted to estimate the potential for producing hydrogen from key renewable resources (onshore wind, solar photovoltaic, and biomass) by county in the United States and to create maps that allow the reader to easily visualize the results. To accomplish this objective, the authors analyzed renewable resource data both statistically and graphically utilizing a stateof-the-art Geographic Information System (GIS), a computer-based information system used to create and visualize geographic information.

Land-use and environmental exclusions were applied to represent the most viable resources across the country. While wind, solar, and biomass are considered major renewable resources, other renewable energy resources could also be used for hydrogen production, thus contributing to hydrogen development locally and regionally. These additional resources include offshore wind, concentrating solar power, geothermal, hydropower, photoelectrochemical, and photobiological resources.

This study found that approximately 1 billion metric tons of hydrogen could be produced annually from wind, solar, and biomass resources in the United States. The greatest potential for producing hydrogen from these key renewable resources is in the Great Plains region. In addition, this research suggests that renewable hydrogen has the potential to displace gasoline consumption in most states if and when a number of technical and scientific barriers can be overcome. 


\section{Contents}

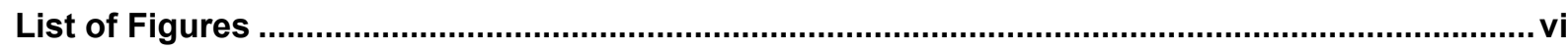

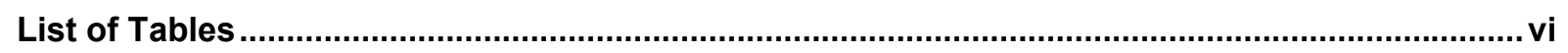

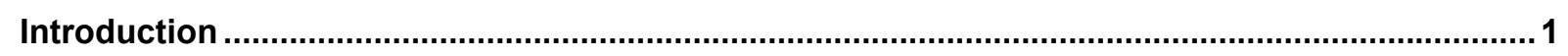

Potential for Hydrogen Production from U.S. Wind Resources.................................................. 2

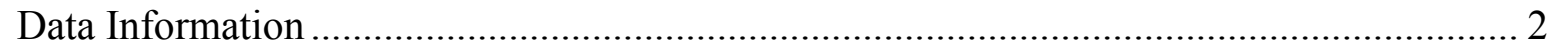

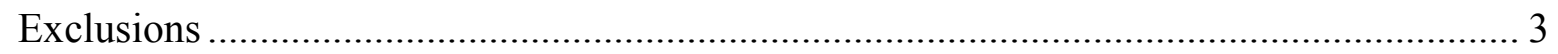

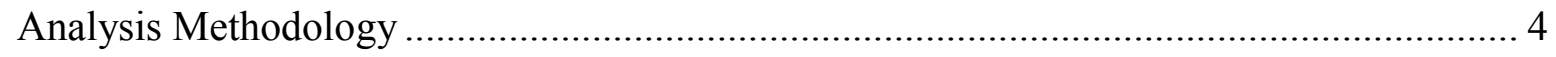

Potential for Hydrogen Production from U.S. Solar Resources ...................................................... 7

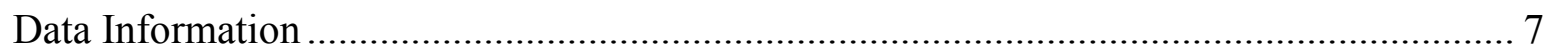

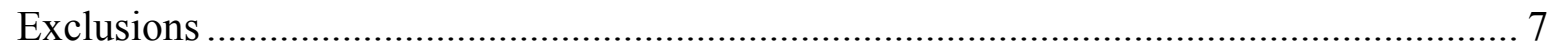

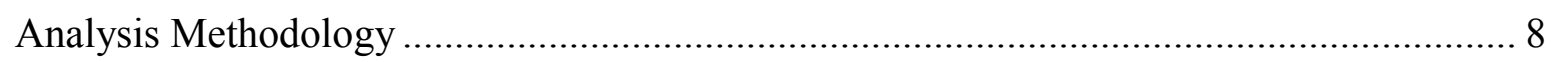

Potential for Hydrogen Production from U.S. Biomass Resources ........................................... 10

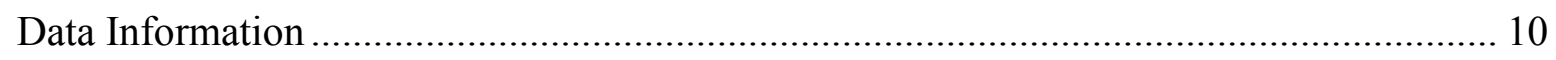

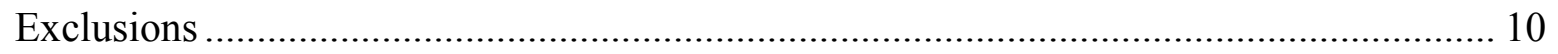

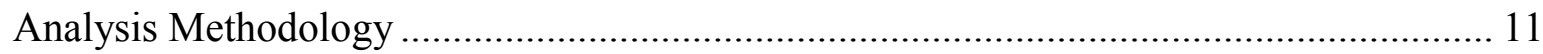

Hydrogen Production Potential from Combined Renewable Resources: Wind, Solar, and

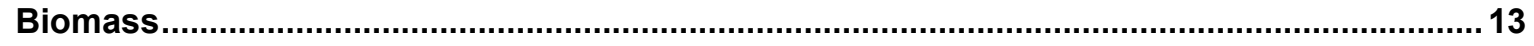

Renewable Hydrogen as a Transportation Fuel ...................................................................... 18

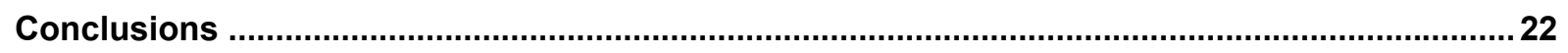

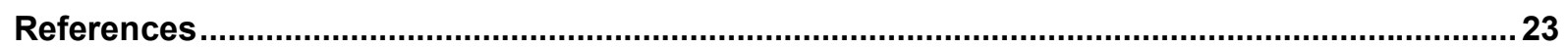




\section{List of Figures}

Figure 1. Available windy lands in the United States .................................................... 2

Figure 2. Environmental and land-use exclusions for U.S. wind resources ......................... 3

Figure 3. Hydrogen production potential from wind resources, by county ......................... 5

Figure 4. Hydrogen production potential from wind resources, per person......................... 6

Figure 5. U.S. solar resource: flat-plate collector tilted at latitude.................................. 7

Figure 6. Environmental and land-use exclusions for solar resources .............................. 8

Figure 7. Hydrogen production potential from solar resources, by county .......................... 9

Figure 8. Hydrogen production potential from solar resources, per person .......................... 9

Figure 9. Available biomass resources in the United States........................................... 10

Figure 10. Hydrogen production potential from biomass resources, by county.................... 11

Figure 11. Hydrogen production potential from biomass resources, per person.................... 12

Figure 12. Hydrogen production potential from renewable resources, by county ................. 13

Figure 13. Hydrogen production potential from dominant renewable resources ................... 14

Figure 14. Hydrogen production potential from renewable resources, per person ................ 14

Figure 15. Population of the United States, by county .................................................. 15

Figure 16. Hydrogen production potential from renewable resources ................................ 17

Figure 17. U.S. gasoline consumption by county, 2002 ............................................. 18

Figure 18. Renewable hydrogen production potential relative to gasoline consumption,

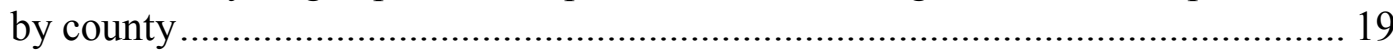

Figure 19. Renewable hydrogen production potential relative to gasoline consumption,

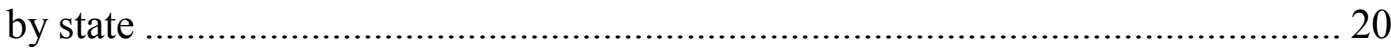

\section{List of Tables}

Table 1. Wind Resource Capacity Factor Used in This Study ......................................... 4

Table 2. Hydrogen Production Potential from Renewable Resources, by State ................. 16

Table 3. Renewable Hydrogen Production Potential Relative to Gasoline Consumption and Population. 


\section{Introduction}

Hydrogen is the simplest element and most plentiful gas in the universe. Today, most hydrogen is produced from fossil fuels, but to most effectively impact the emissions and energy import balances associated with transportation fuels, hydrogen must be produced from domestically available renewable resources such as wind, solar, and biomass.

There are many options for producing hydrogen from renewable resources. This study considers hydrogen production using wind and solar electrolysis as well as gasification and steam methane reforming methods for converting biomass to hydrogen.

The electrolysis process involves the use of wind- or solar-generated electricity. In this study, a wind turbine is assumed to be used to produce electricity from the wind, and photovoltaic (solar electric) systems are assumed to be used to produce electricity from solar resources. This renewably produced electricity is then used in an electrolyzer, a device that uses electricity to split water into hydrogen and oxygen.

Biomass gasification is the conversion, by partial oxidation at high temperature, of a carbonaceous feedstock (agricultural and woody residues) into a gaseous fuel which is then reformed to produce hydrogen. In the steam methane reforming process, high-temperature steam and a nickel catalyst are used to produce hydrogen from a methane source (such as landfill gas, animal manure, and wastewater sludge).

The objective of this study was to estimate the potential for producing hydrogen from key renewable resources (onshore wind, solar photovoltaic, and biomass) by county for the United States, and to create maps for easy visualization of the results. To accomplish this objective, renewable resource data are analyzed both statistically and graphically utilizing a state-of-theart Geographic Information System (GIS), a computer-based information system used to create, manipulate, analyze, and visualize geographic information.

Land-use and environmental exclusions were applied to this study to represent the most viable resources across the country. While wind, solar, and biomass are considered major renewable resources, other renewable energy resources could also be used for hydrogen production, thus contributing to hydrogen development locally and regionally. Future analyses could include studying the use of offshore wind, concentrating solar power, geothermal, hydropower, photoelectrochemical, and photobiological resources for hydrogen production. 


\section{Potential for Hydrogen Production from U.S. Wind Resources}

\section{Data Information}

This analysis used updated wind resource data where available at the time the analysis was completed for California, Connecticut, Delaware, Idaho, Illinois, Maine, Maryland, Massachusetts, Montana, New Hampshire, New Jersey, New Mexico, North Carolina, North Dakota, Oregon, Pennsylvania, Rhode Island, South Dakota, Vermont, Virginia, Washington, West Virginia and Wyoming. These data were then combined with low-resolution 1987 U.S. wind resource data. The grid cell resolution of these data varies from $200 \mathrm{~m}^{2}-1 \mathrm{~km}^{2}$ for the high-resolution data and is $25 \mathrm{~km}^{2}$ for the low-resolution 1987 wind data (Figure 1).

The study considers areas with class 3 annual average wind speeds and greater, at $50 \mathrm{~m}$ above ground. These areas are suitable for most utility-scale wind turbine applications, whereas class 2 areas are marginal for utility-scale applications (some may be suitable for rural applications). Class 1 areas are generally not suitable for wind turbine installations. The degree of certainty with which the wind power class can be specified depends on three factors: the abundance and quality of wind data, the complexity of the terrain, and the geographical variability of the resource. $^{1}$

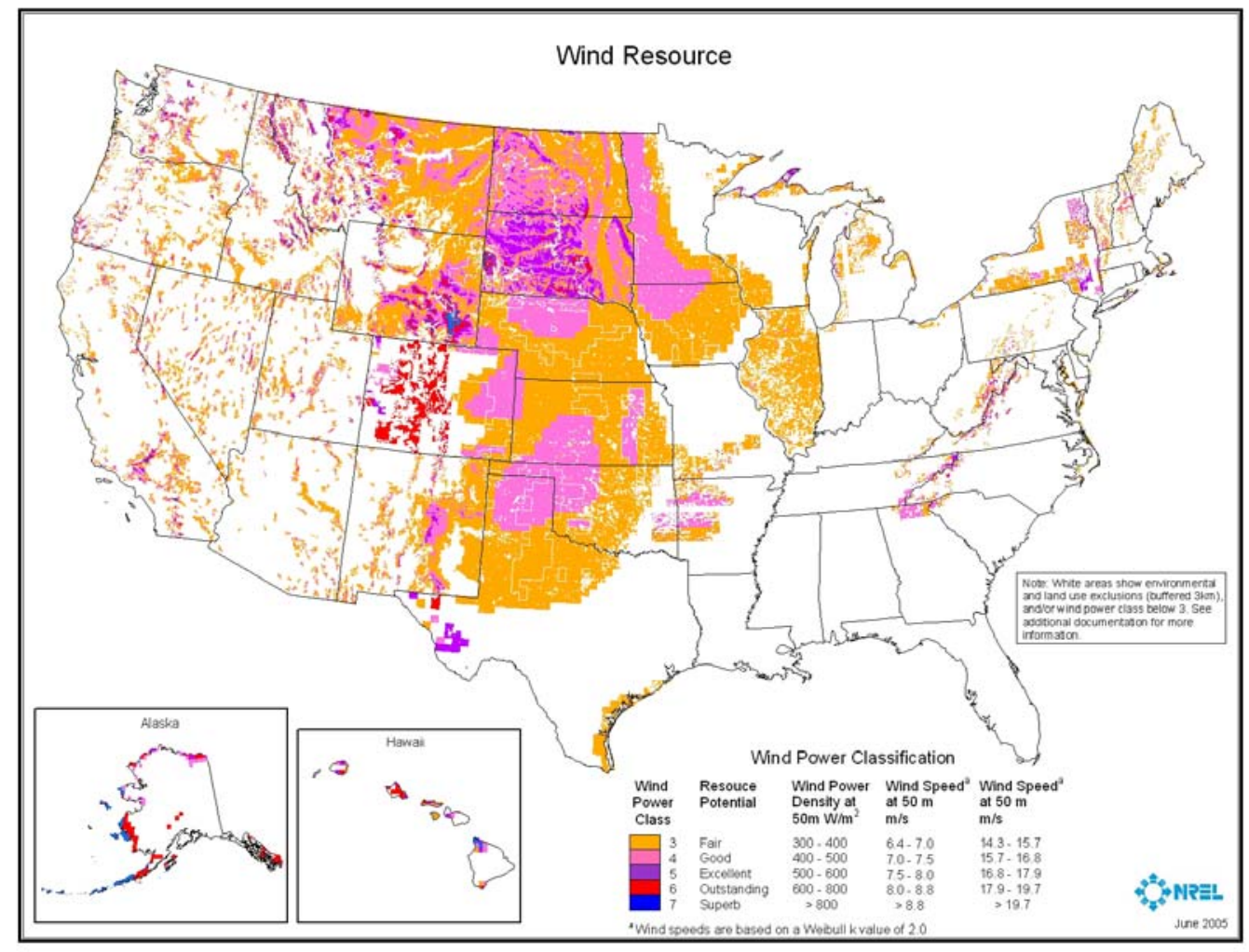

Figure 1. Available windy lands in the United States

\footnotetext{
${ }^{1}$ Wind data and maps, National Renewable Energy Laboratory, Golden, CO: http://www.nrel.gov/gis/wind.html, March 2005.
} 


\section{Exclusions}

The following topographic, land use and environmental exclusions were applied to the analysis of the potential for hydrogen production from wind in this study:

- Completely excluded were areas with slopes greater than $20 \%$ for the high-resolution data. These areas maybe too steep for siting wind turbines.

- Environmental and land-use exclusions (Figure 2) were defined to account for lands where wind energy development would be prohibited or severely restricted.

- 100\% excluded: All National Park Service areas; Fish and Wildlife Service lands; all federal lands with a special designation (parks, wilderness, wilderness and study areas, wildlife refuges, wildlife areas, recreational areas, battlefields, monuments, conservation areas, recreational areas, and wild and scenic rivers); conservation areas; water; wetlands; urban areas; and airports/airfields.

- $50 \%$ excluded: The remaining Forest Service and Department of Defense lands and non-ridge-crest forests.

- Entirely excluded: The 3-km area surrounding $100 \%$ environmental and land-use exclusions, except for water bodies.

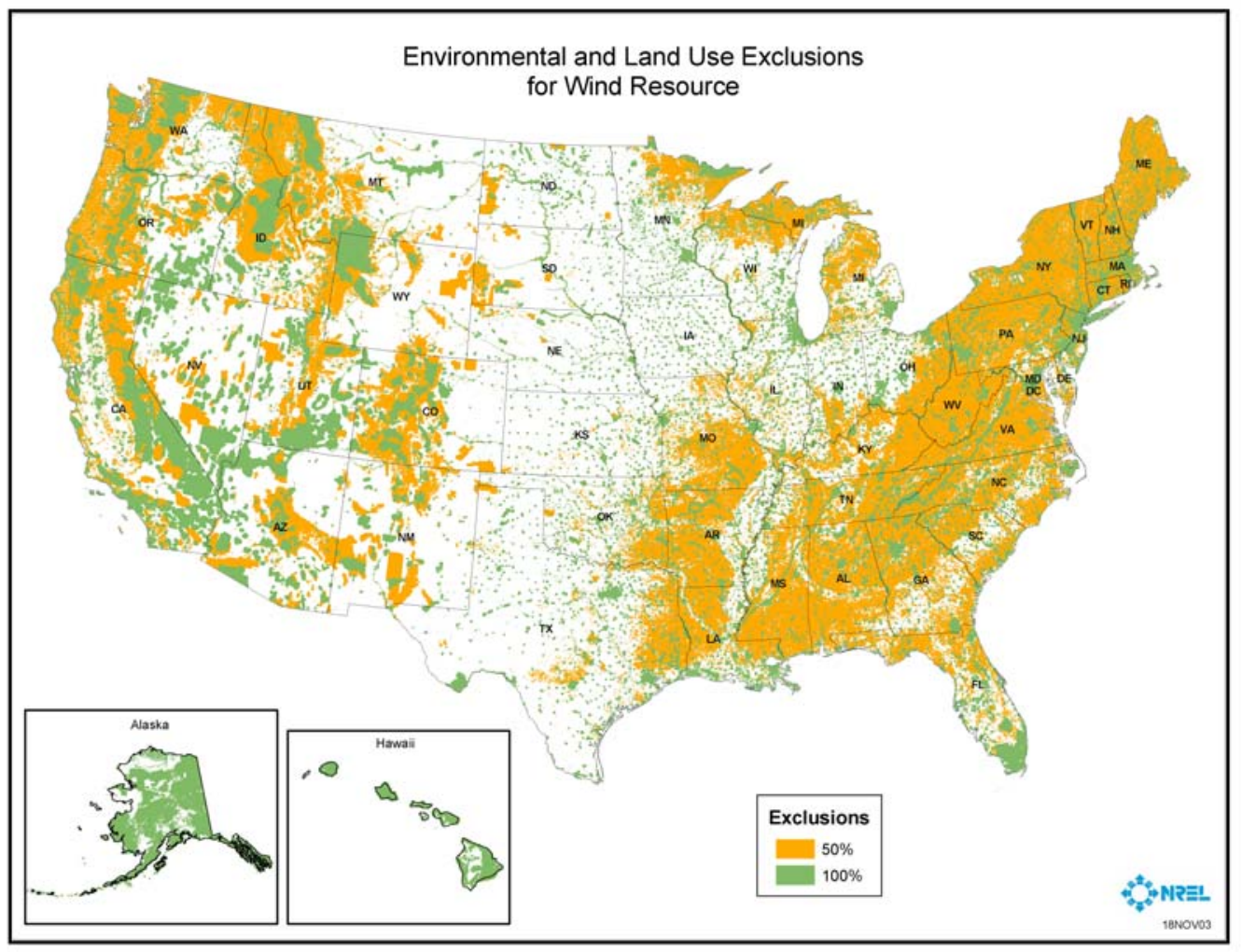

Figure 2. Environmental and land-use exclusions for U.S. wind resources

Additional analysis was performed for the high- and low-resolution data sets:

- Terrain (low-resolution data set only): The low-resolution 1987 wind resource data have assigned to each $25 \mathrm{~km}^{2}$ grid cell a terrain exposure factor that represents the type of wind 
climate for exposed features in that grid cell. The terrain factors are 5\% exposed for ridgecrest wind, $35 \%$ or $65 \%$ for hilly areas, and $90 \%$ for generally flat terrain.

- Minimum density (high-resolution data set only): Minimum density criteria of $5 \mathrm{~km}^{2}$ per $100 \mathrm{~km}^{2}$ of class 3 or better wind resources were applied to the high-resolution data. The purpose of this density analysis is to eliminate small, isolated wind resource areas with a low likelihood of development.

\section{Analysis Methodology}

After the exclusions were applied to the wind resource information, the low- and highresolution data were merged together to create the final wind resource file used to summarize the data by county (Figure 1). Installed nameplate capacity was subsequently calculated, assuming $5 \mathrm{MW} / \mathrm{km}^{2}$ conversion, and applied to the class 3 or better lands. Table 1 below shows the capacity factor ${ }^{2}$ used for this study.

\section{Table 1. Wind Resource Capacity Factor Used in This Study}

\begin{tabular}{|c|l|l|}
\hline Class & Year & Capacity Factor \\
\hline 3 & 2000 & 0.2 \\
\hline 4 & 2000 & 0.251 \\
\hline 5 & 2000 & 0.3225 \\
\hline 6 & 2000 & 0.394 \\
\hline 7 & 2000 & 0.394 \\
\hline
\end{tabular}

Source: Power Technologies Energy Data Book ${ }^{3}$

An average hydrogen production rate of $58.8 \mathrm{kWh} / \mathrm{kg}$ hydrogen was applied to the final wind dataset, and the total kilograms of hydrogen per county per year were calculated. This hydrogen production rate assumes a $66.3 \%$ efficient electrolysis system (higher heating value basis). Typical energy requirements for electrolysis systems range from 53-70 kWh/kg (Ivy 2004), and larger systems have higher efficiencies. The average of the efficiencies of today's electrolyzers from Proton, Avalence, Teledyne, Stuart, and Norsk-Hydro is $58.8 \mathrm{kWh} / \mathrm{kg}$.

Figure 3 illustrates the potential to produce hydrogen from wind in the United States, normalized by county area. Normalization is dividing one numeric value by another to minimize differences in values based on the size of areas. In this study, normalizing the hydrogen from renewable resources (wind, solar or biomass) by county areas, yields hydrogen from these resources per unit area $\left(\mathrm{km}^{2}\right)$. This allows transforming the data's measurements so that they can be compared regardless of the size of the counties. For example, a map of the raw hydrogen potential from all renewable resources by county would reveal that many large counties in the West have more resources than most of the counties east of the Mississippi River. A normalized map (Figure 12) reveals that, once the size of the county is factored out, some small counties in the East have similar values as some large counties west of the Mississippi River.

\footnotetext{
${ }^{2}$ Capacity factor is defined as the wind turbine's actual energy output divided by the rated maximum turbine output for the year. When the wind turbine's capacity factor at a given average annual wind speed is known, it allows a reliable calculation of the expected energy output per year. A reasonable capacity factor is 0.25 to 0.30 . A very good capacity factor is 0.40 .

${ }^{3}$ Power Technologies Energy Data Book, National Renewable Energy Laboratory, Golden, CO: http://www.nrel.gov/analysis/power databook/, March 2005
} 


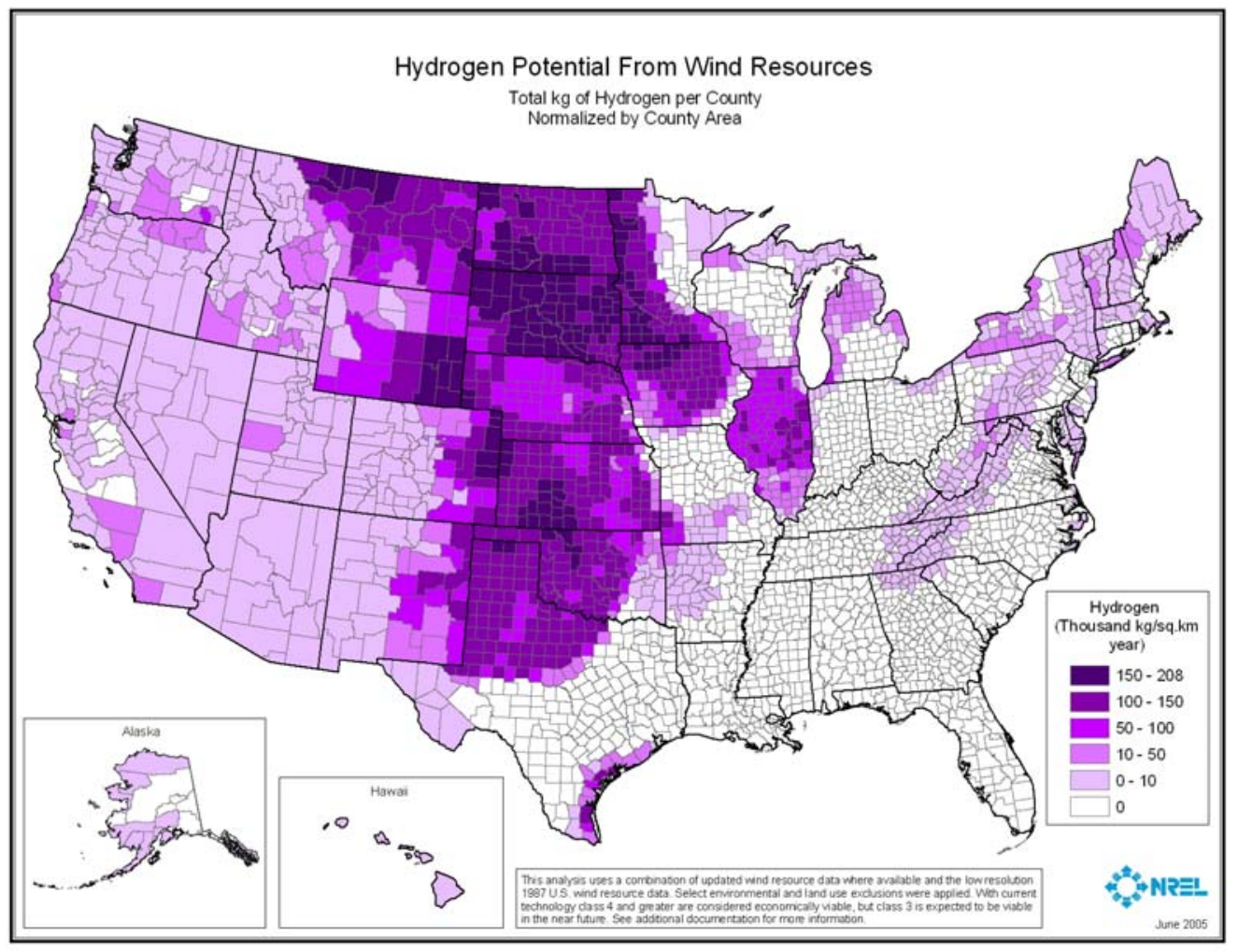

Figure 3. Hydrogen production potential from wind resources, by county

Figure 4 shows the amount of hydrogen that could be produced from wind per person in each county. Less populated counties in the Great Plains combined with very good wind resources define the high hydrogen potential from wind resources per person in this region. 


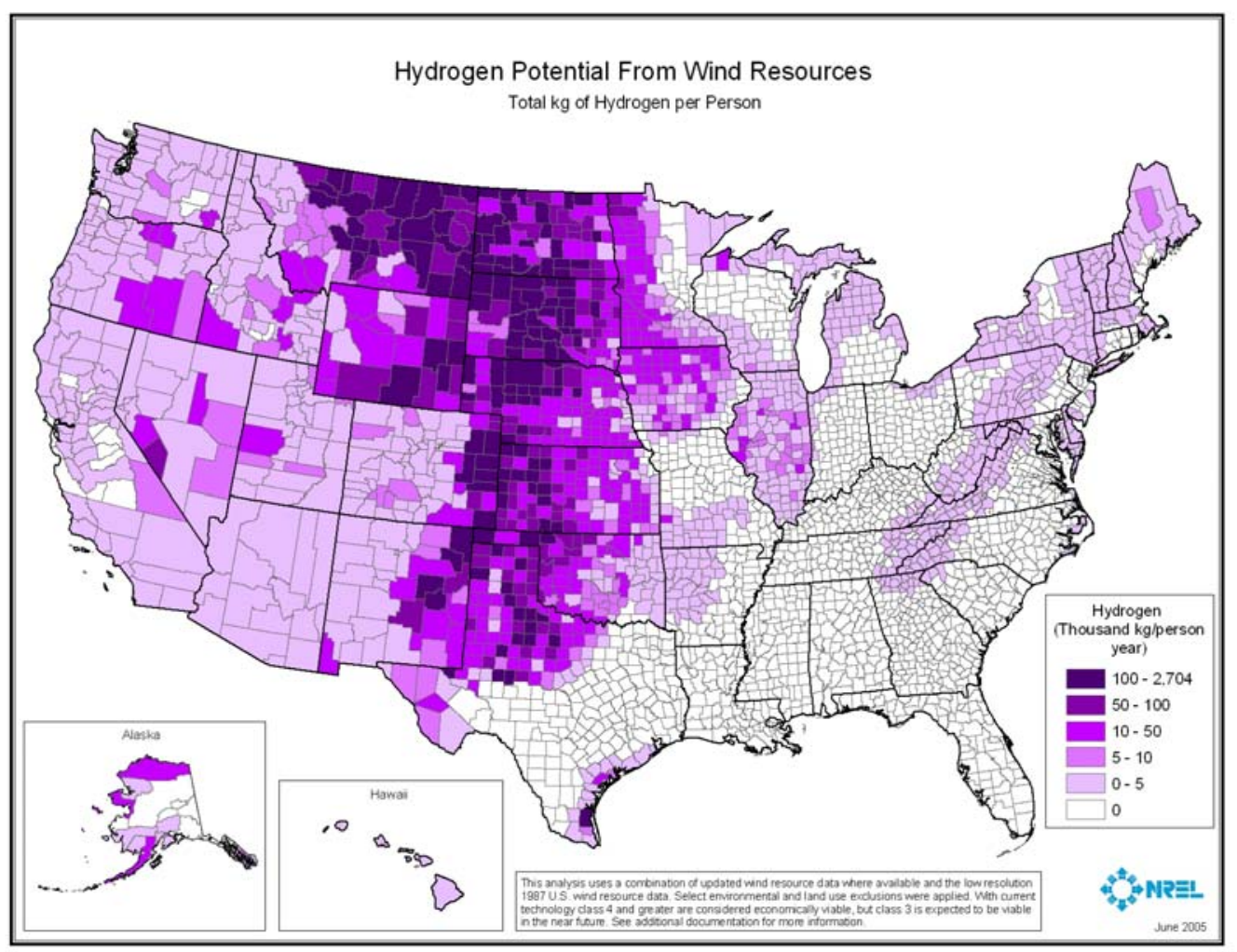

Figure 4. Hydrogen production potential from wind resources, per person 


\section{Potential for Hydrogen Production from U.S. Solar Resources}

\section{Data Information}

This analysis uses solar resources available for nontracking flat-plate collectors oriented toward the south at latitude tilt. Estimates of annual average daily total global radiation falling on these collectors are modeled using inputs derived from satellite and surface cloud cover observations as well as other key meteorological variables. The cloud cover observations are on a $40-\mathrm{km}^{2}$ resolution grid representing the period 1985-1991. Values range from about 2.2 $\mathrm{kWh} / \mathrm{m}^{2} /$ day in portions of Alaska to about $7.0 \mathrm{kWh} / \mathrm{m}^{2} /$ day in portions of the Southwestern United States (Figure 5). ${ }^{4}$

\section{Exclusions}

These environmental and land use exclusions were applied to the solar resources (Figure 6):

- $100 \%$ excluded: All National Park Service areas; Fish and Wildlife Service lands; all federal lands with a specific designation (parks, wilderness, wilderness and study areas, wildlife refuges, wildlife areas, recreational areas, battlefields, monuments, conservation areas, recreational areas, and wild and scenic rivers), conservation areas, water, wetlands, and airports/airfields.

- Also $100 \%$ excluded: A 3-km area surrounding environmental and land-use exclusions, except for water bodies.

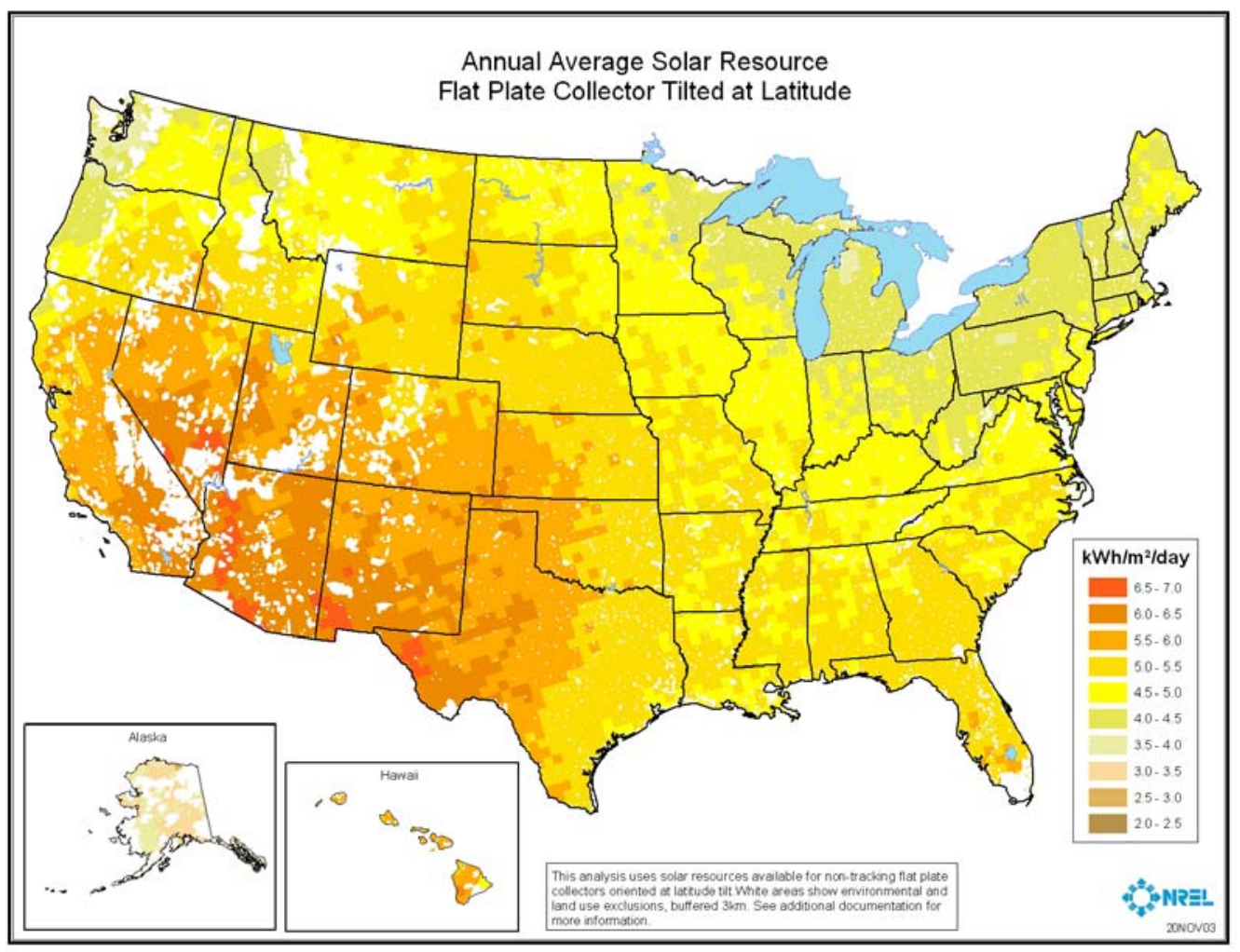

Figure 5. U.S. solar resource: flat-plate collector tilted at latitude

\footnotetext{
${ }^{4}$ Solar data and maps, National Renewable Energy Laboratory, Golden, CO: http://www.nrel.gov/gis/solar.html, March 2006
} 


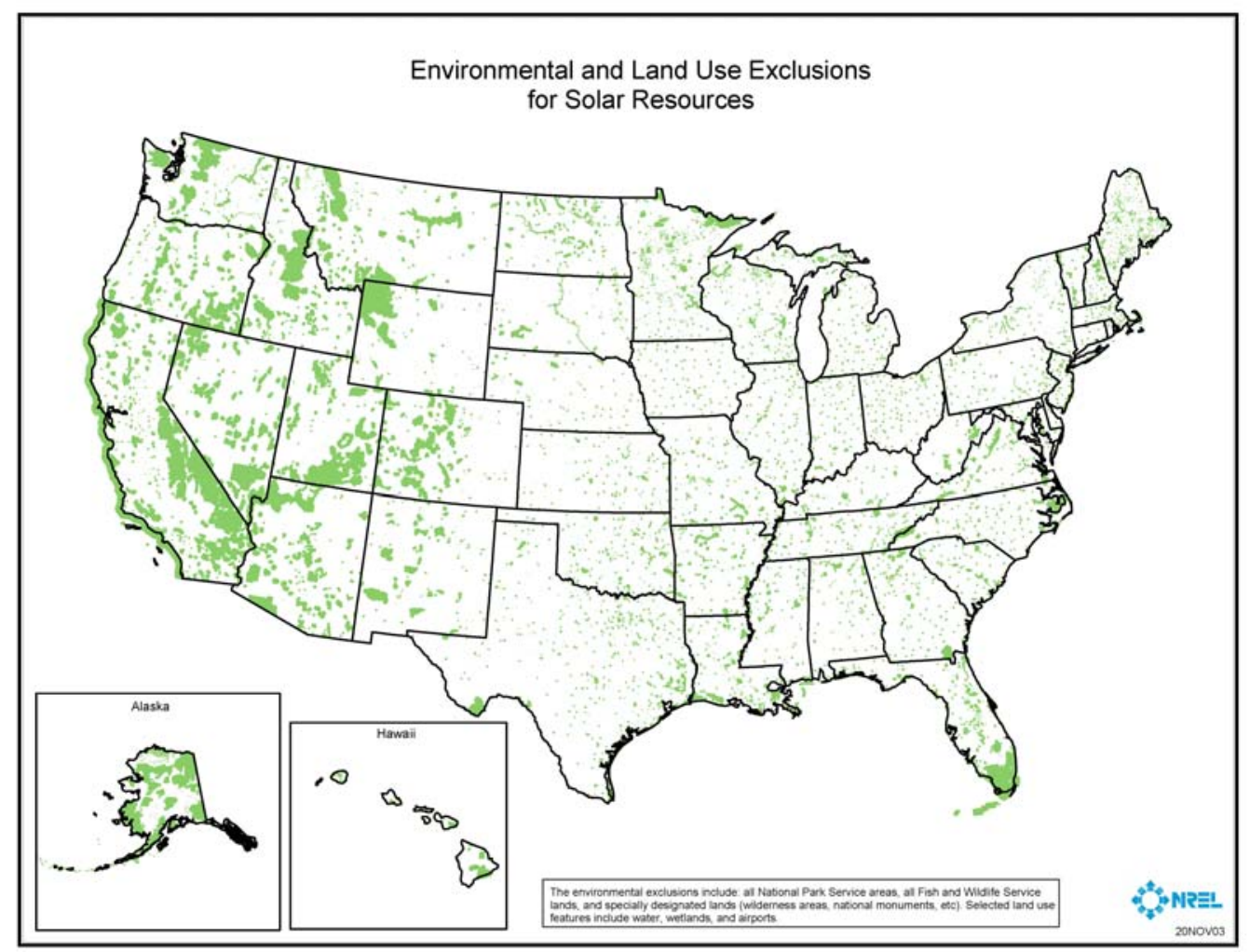

Figure 6. Environmental and land-use exclusions for solar resources

\section{Analysis Methodology}

It was assumed that any given $40-\mathrm{km}$ by $40-\mathrm{km}$ cell will have no more than $10 \%$ of its land area dedicated to photovoltaic development, and only $30 \%$ of this area will be covered with solar panels. The photovoltaic solar panels are assumed to have a solar-to-electricity conversion efficiency of $10 \%$. As with the analysis of the hydrogen production potential via wind electrolysis, the electricity requirement of the electrolysis system was assumed to be 58.8 $\mathrm{kWh} / \mathrm{kg}$ hydrogen, or approximately $66.3 \%$ on a higher heating value basis.

Figure 7 depicts the hydrogen production potential from solar-driven electrolysis normalized by county; the Southwest is shown to have the highest potential. Similar to the wind analysis results, counties with very good solar resources and low population count (such as the Rocky Mountain-Great Plains region) clearly show high potential for producing hydrogen from solar resources, per person (Figure 8). 


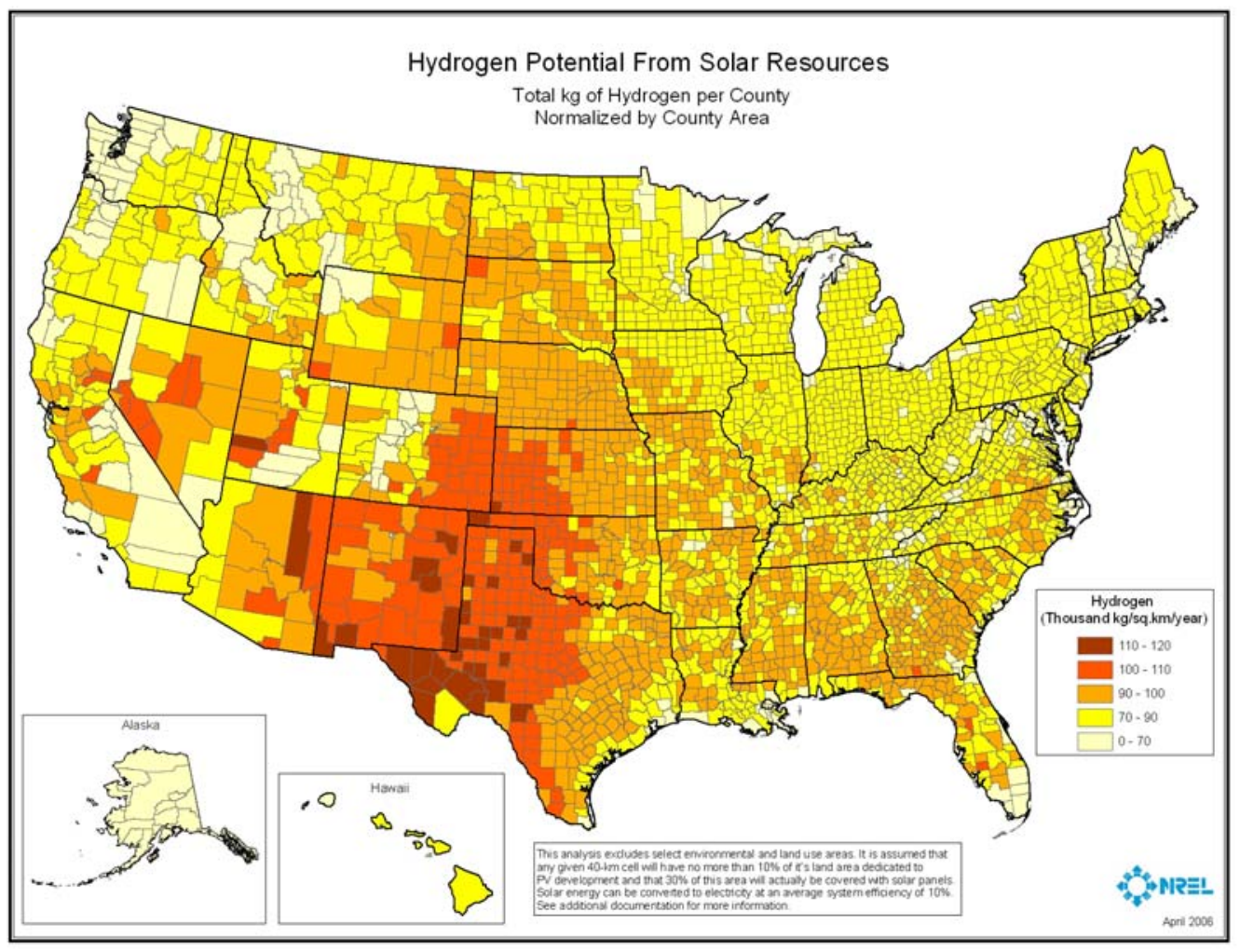

Figure 7. Hydrogen production potential from solar resources, by county

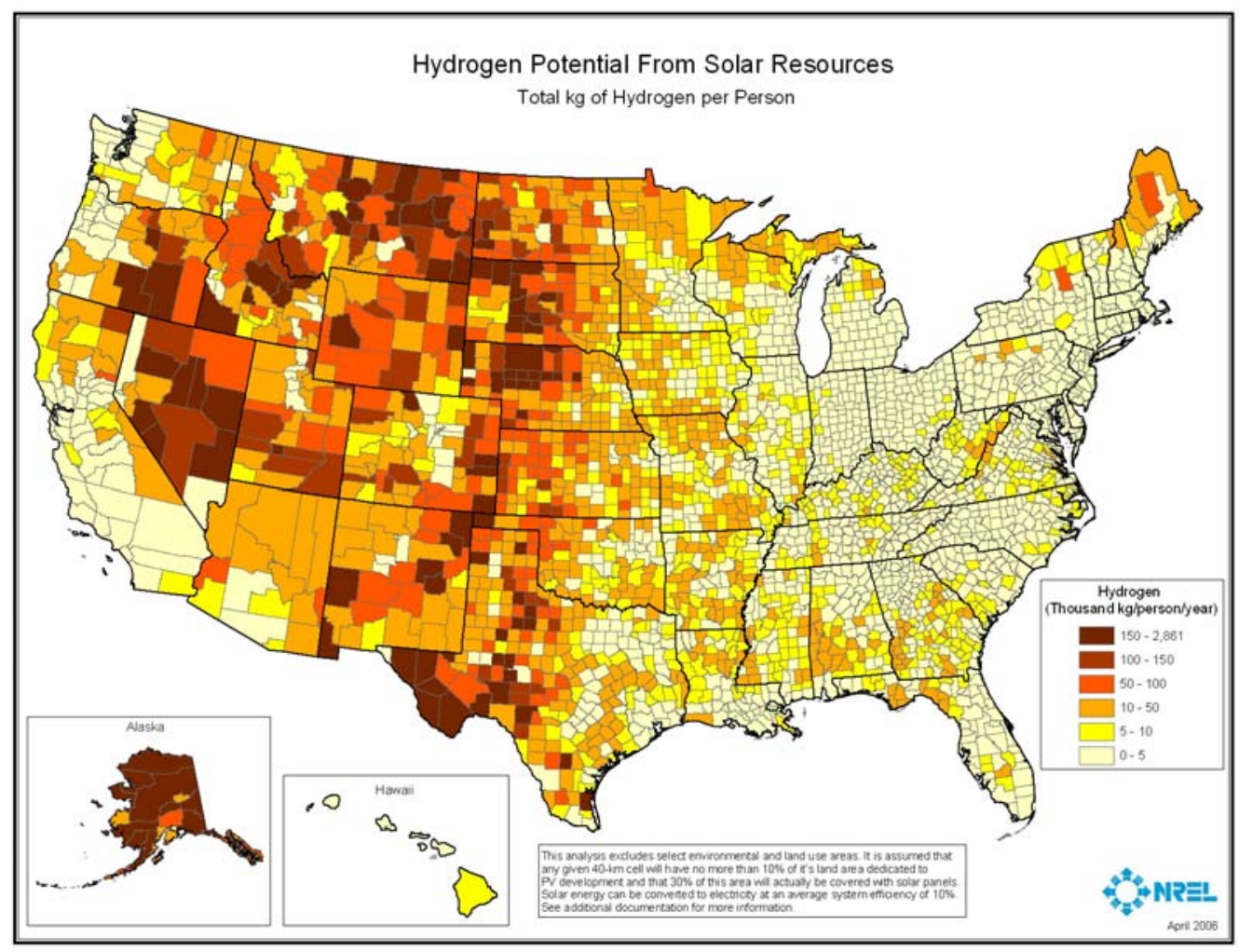

Figure 8. Hydrogen production potential from solar resources, per person 


\section{Potential for Hydrogen Production from U.S. Biomass Resources}

\section{Data Information}

The assessment of the hydrogen production potential from biomass is based on a recently published study by the National Renewable Energy Laboratory (NREL) of biomass resource availability in the United States by county. It includes the following feedstock categories: agricultural residues (crop residues and animal manure); wood residues (forest residues, primary and secondary mill residues, urban wood waste); municipal discards (methane emissions from landfills and domestic wastewater treatment); and dedicated energy crops (switchgrass on Conservation Reserve Program lands). Each feedstock category was processed using the appropriate methodology, as described in the milestone report (Milbrandt 2005), to estimate the biomass potential by county depicted in Figure $9 .^{5}$

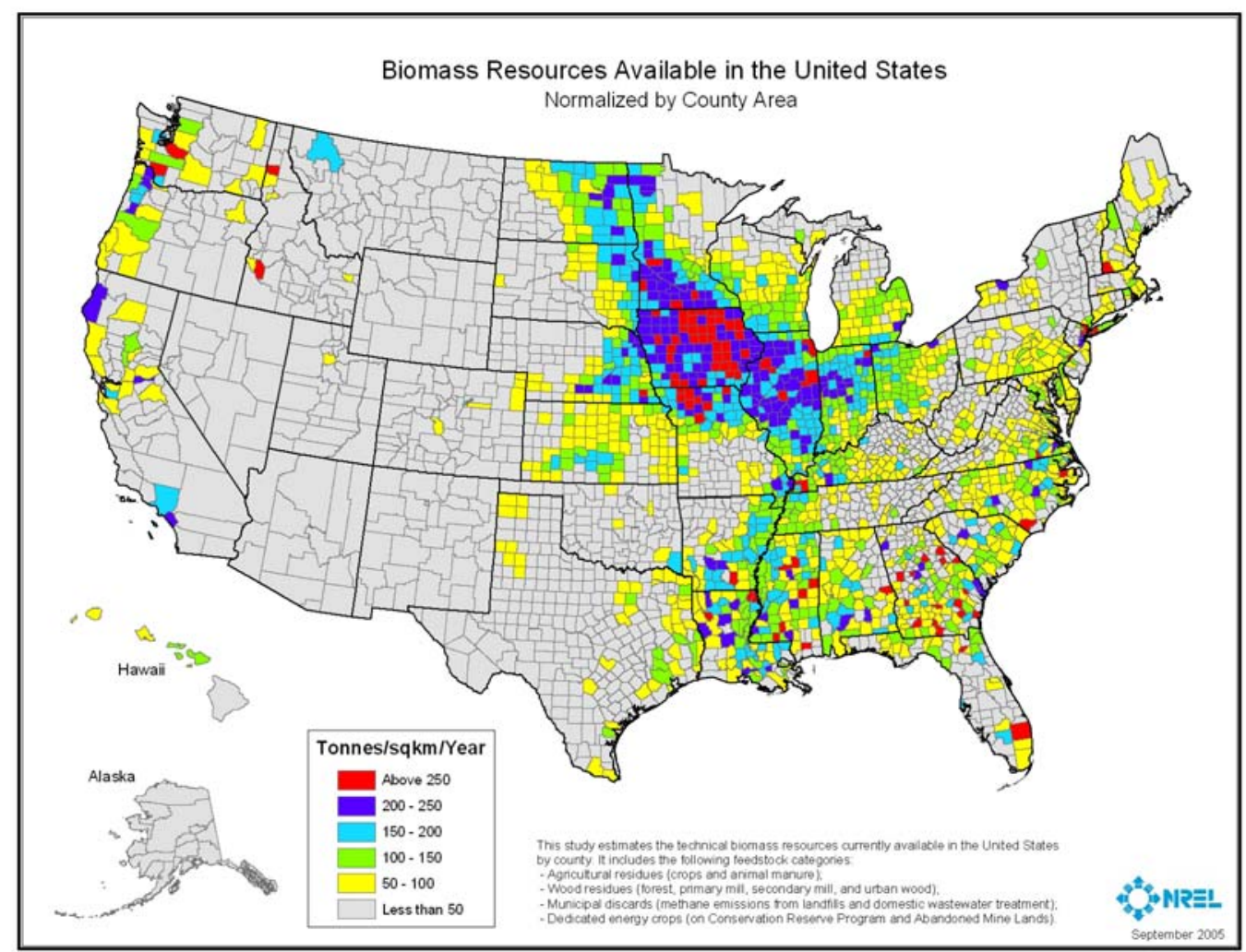

Figure 9. Available biomass resources in the United States

\section{Exclusions}

Because of the wide range of feedstock types, biomass is available from many sources and has a broad geographic distribution. Therefore, it is difficult to define land use and environmental exclusions that would be applicable to all categories. Additional study is needed to improve the spatial distribution of biomass resources to define excluded areas appropriately.

\footnotetext{
${ }^{5}$ Biomass data and maps, National Renewable Energy Laboratory, Golden, CO: http://www.nrel.gov/gis/biomass.html, March 2006
} 


\section{Analysis Methodology}

Different conversion rates of biomass to hydrogen were used, depending on the feedstock. For crops and woody residues, a relationship formula of $13.8 \mathrm{~kg}$ bone dry weight (BDW)/kg hydrogen was applied. This rate is based on the conversion of lignocellulosic plant material to hydrogen via gasification analyzed by the U.S. Department of Energy's Hydrogen Analysis (H2A) Group. ${ }^{6}$ For gaseous feedstock (methane emissions from manure management, landfills, and domestic wastewater treatment), a conversion of $2.34 \mathrm{~kg}$ methane $/ \mathrm{kg}$ hydrogen was used. This value represents $85 \%$ conversion efficiency from the stoichiometric maximum possible from steam reforming of methane. Figure 10 illustrates the results of this analysis. Counties in the Midwest, along the Mississippi River, and in the Southeast show the highest potential for hydrogen production from biomass as a result of the large quantities of crop, forest, and primary mill residues. High amounts of secondary mill and urban wood residues, as well as methane emission from landfills and domestic wastewater treatment, contribute to the high potential for hydrogen production from biomass in the New York metropolitan area. The counties in the Midwest and Great Plains with their low population counts and good biomass resources contribute to the high amount of hydrogen from biomass per person (Figure 11).

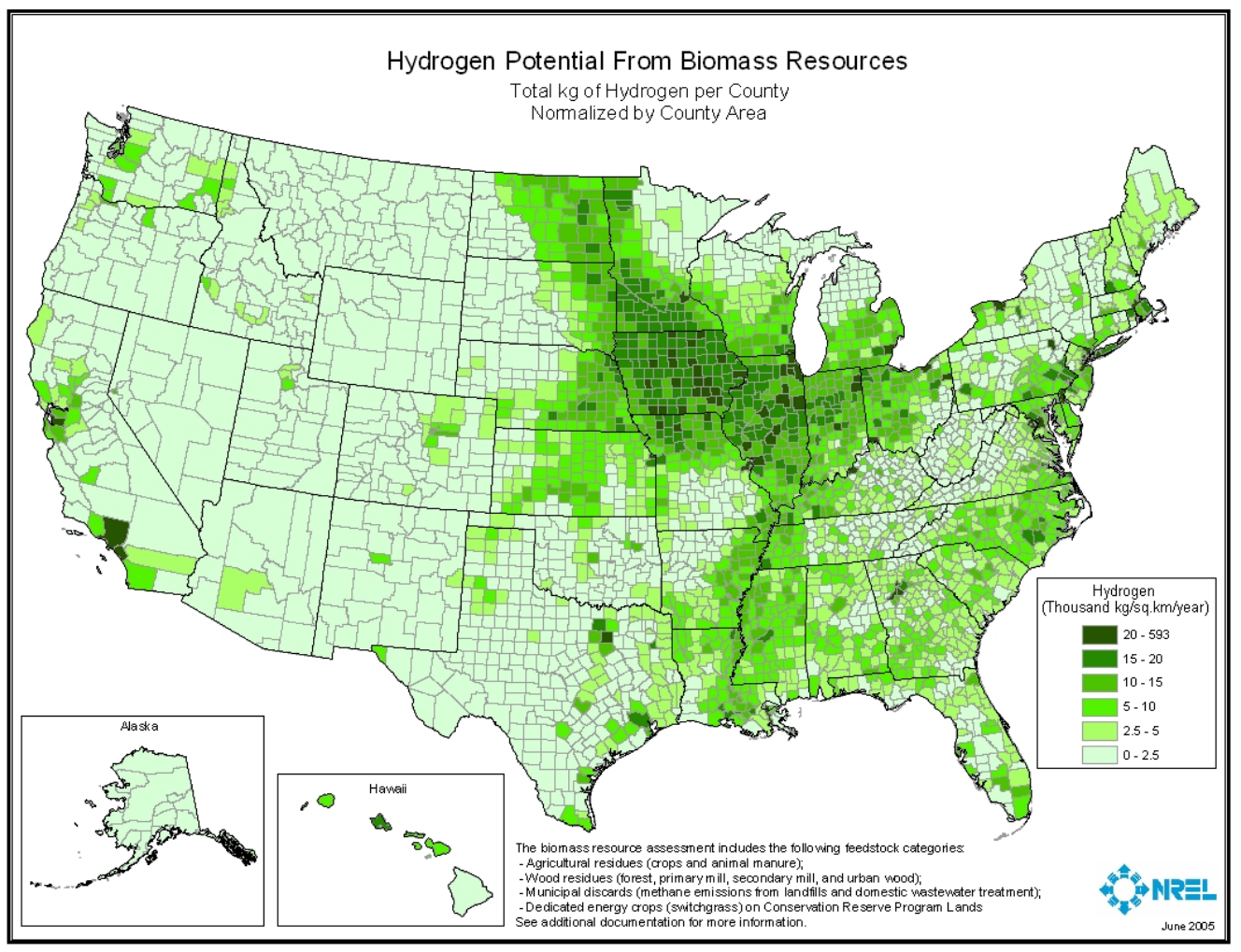

Figure 10. Hydrogen production potential from biomass resources, by county

\footnotetext{
${ }^{6}$ The Hydrogen Analysis (H2A) Project: http://www.hydrogen.energy.gov/h2a analysis.html
} 


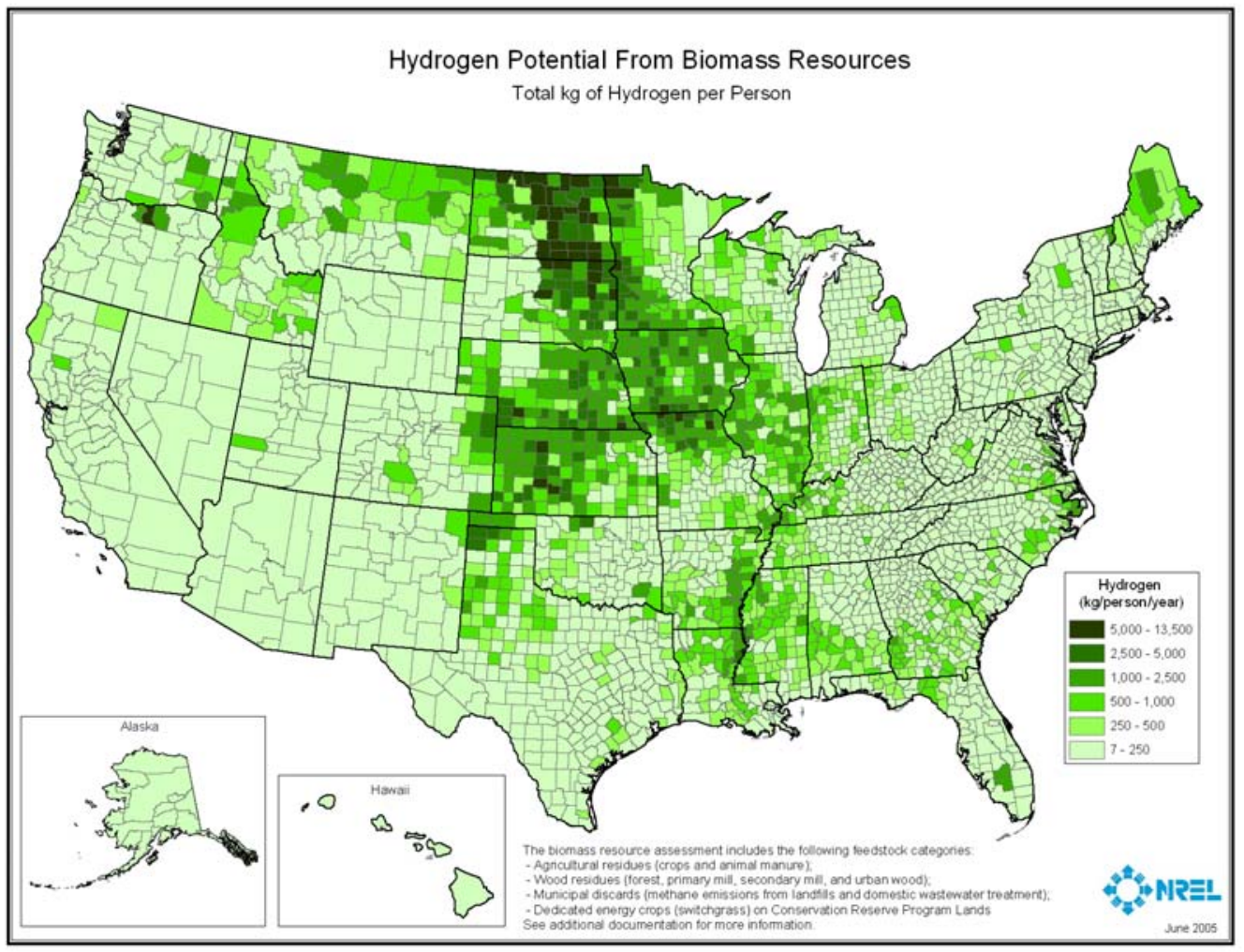

Figure 11. Hydrogen production potential from biomass resources, per person 


\section{Hydrogen Production Potential from Combined Renewable Resources: Wind, Solar, and Biomass}

The results from the previous three analyses were combined to illustrate the total amount of hydrogen that could be produced from renewable resources by county (Figure 12). The large quantities of wind, solar, and biomass resources in the Great Plains are the reason for the high potential for hydrogen production from renewable resources in this region. Figure 13 gives further details on whether the highest amount of hydrogen in each county comes from wind, solar, or biomass - in other words, which one is the dominant renewable resource.

Wind is the leading resource for hydrogen production in many counties in the central states and solar is a dominant resource in the rest of the country; the highest values are in the Southwest. Hydrogen from biomass has higher values than hydrogen from wind and solar in only a few counties - New York and Miami metropolitan areas - because of activities related to high concentrations of people, such as the generation of waste. The results by state are presented in Table 2 and Figure 16. The amount of hydrogen from combined renewable resources per person is shown in Figure 14, and Figure 15 illustrates the geographic distribution of the population. The Rocky Mountain-Great Plains region shows the highest potential quantity of renewable hydrogen per person because of its low population count and large amount of renewable resources.

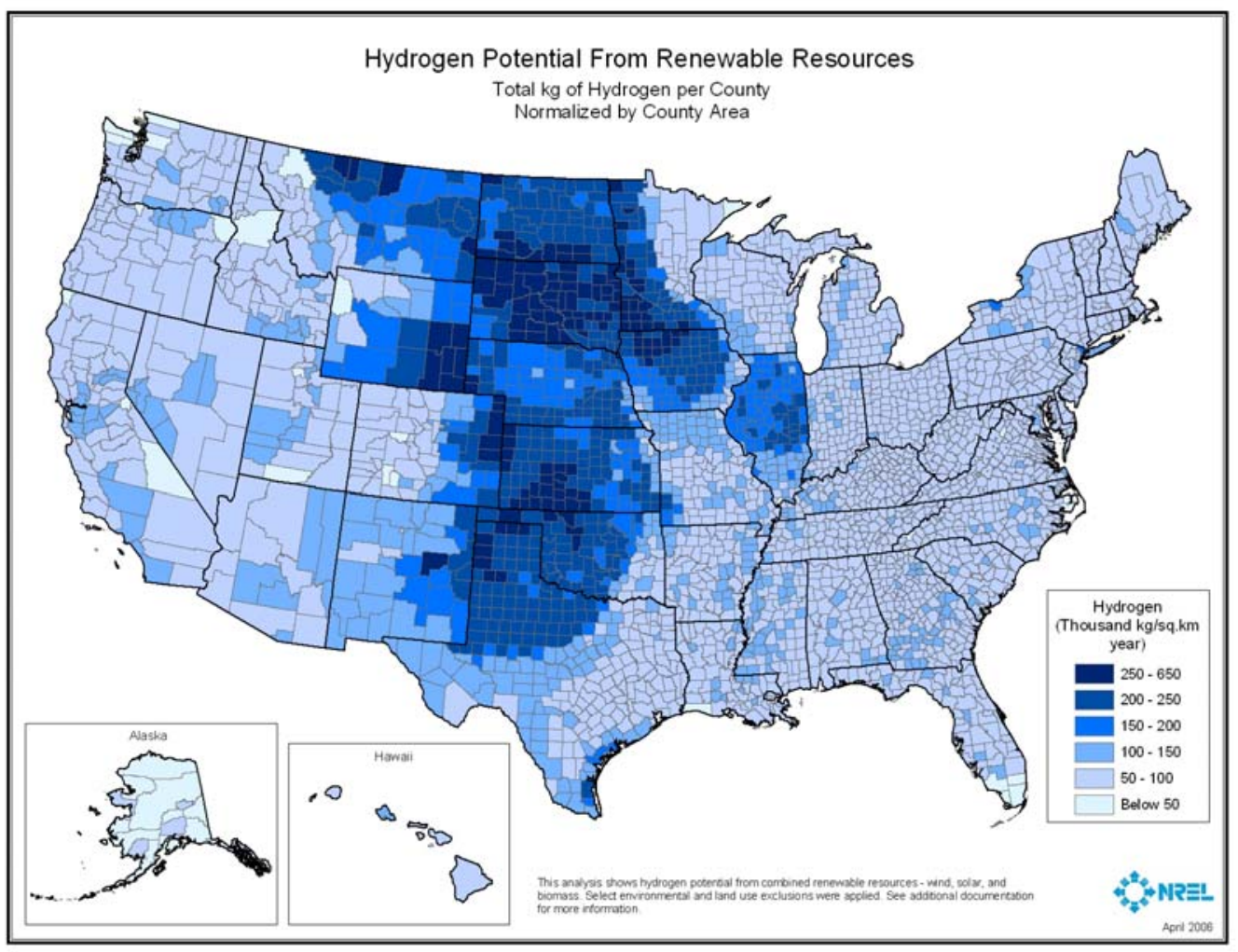

Figure 12. Hydrogen production potential from renewable resources, by county 


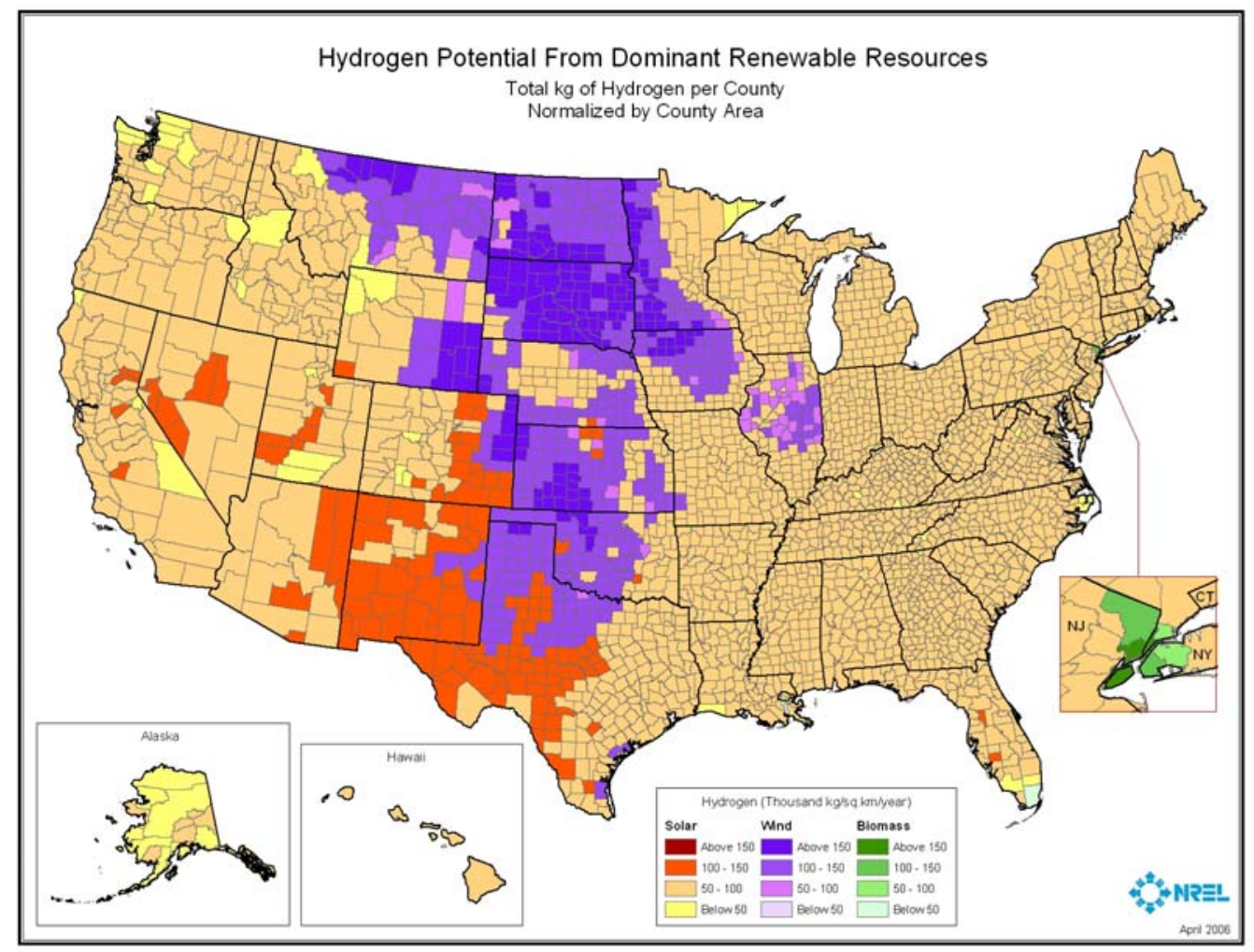

Figure 13. Hydrogen production potential from dominant renewable resources

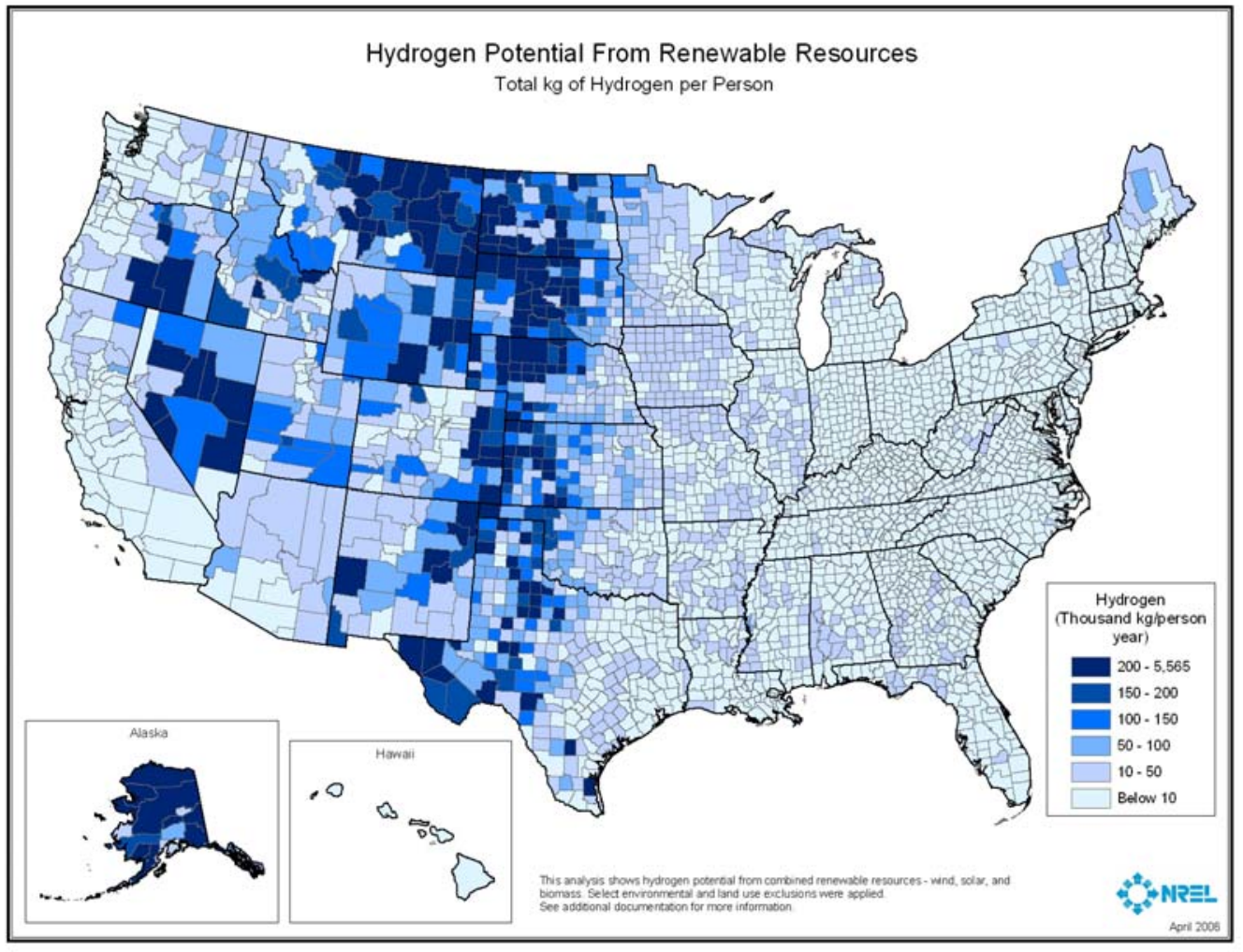

Figure 14. Hydrogen production potential from renewable resources, per person 


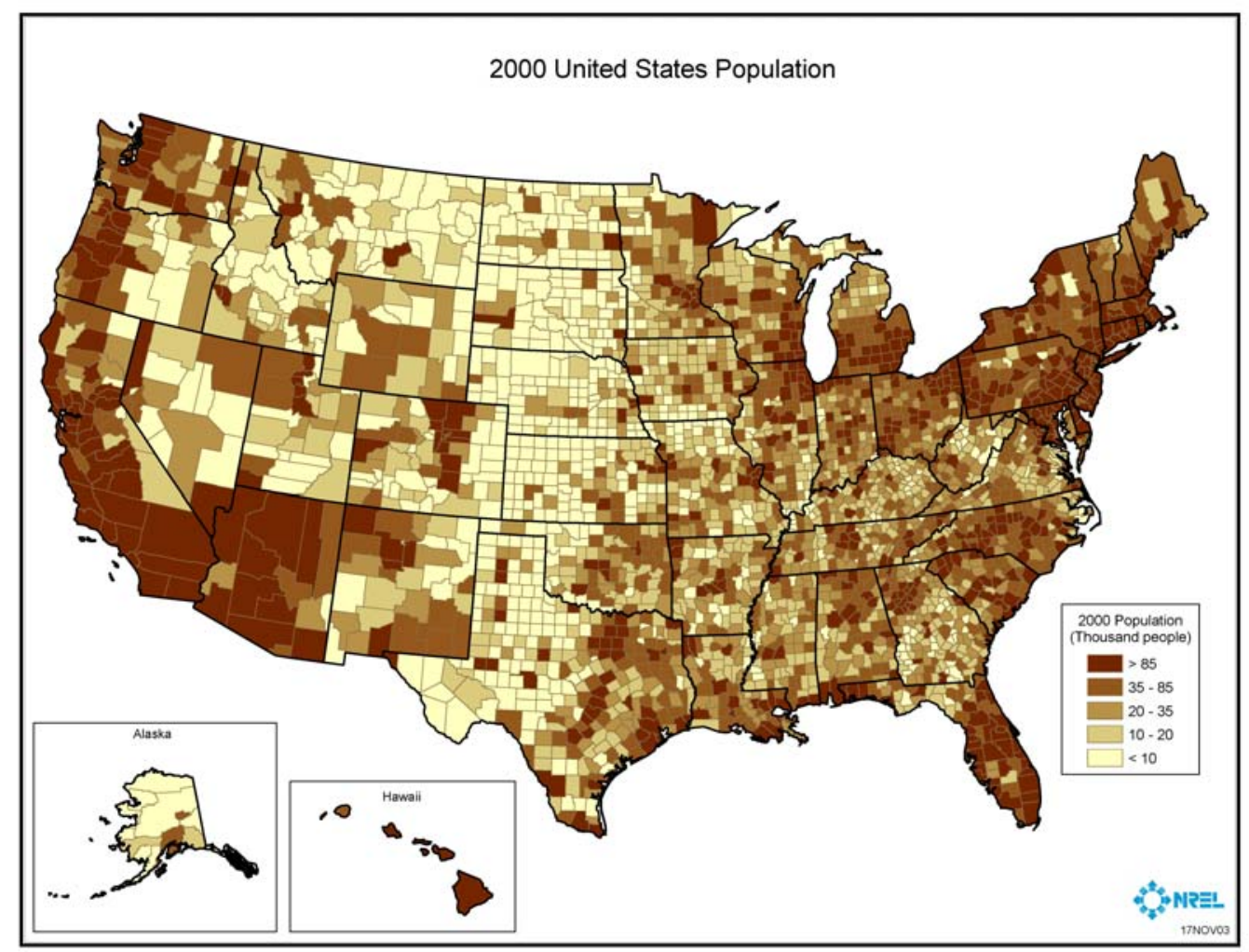

Figure 15. Population of the United States, by county 
Table 2. Hydrogen Production Potential from Renewable Resources, by State

\begin{tabular}{|c|c|c|c|c|c|c|c|c|}
\hline State & 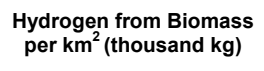 & $\begin{array}{c}\text { Hydrogen from Biomass } \\
\text { (million } \mathrm{kg})\end{array}$ & $\begin{array}{l}\text { Hydrogen from Solar } \\
\text { per } \mathbf{k m}^{2} \text { (thousand kg) }\end{array}$ & $\begin{array}{l}\text { Hydrogen from Solar } \\
\text { (million kg) }\end{array}$ & $\begin{array}{l}\text { Hydrogen from Wind } \\
\text { per } \mathrm{km}^{2} \text { (thousand } \mathrm{kg} \text { ) }\end{array}$ & $\begin{array}{l}\text { Hydrogen from Wind } \\
(\text { million } \mathrm{kg})\end{array}$ & $\begin{array}{l}\text { Total Hydrogen per km² } \\
\text { (thousand kg) }\end{array}$ & $\begin{array}{l}\text { Total Hydrogen } \\
\text { (million kg) }\end{array}$ \\
\hline Alabama & 293 & 588 & 6,003 & 12,014 & 0 & 0 & 6,296 & 12,602 \\
\hline Alaska & 5 & 73 & 901 & 51,887 & 19 & 868 & 926 & 52,828 \\
\hline Arizona & 7 & 142 & 1,413 & 27,433 & 28 & 727 & 1,448 & 28,302 \\
\hline Arkansas & 394 & 729 & 6,618 & 12,102 & 145 & 308 & 7,156 & 13,139 \\
\hline California & 314 & 1,165 & 4,536 & 29,926 & 215 & 2,309 & 5,066 & 33,401 \\
\hline Colorado & 93 & 289 & 5,422 & 24,036 & 2,244 & 10,669 & 7,759 & 34,994 \\
\hline Connecticut & 37 & 64 & 621 & 1,004 & 1 & 1 & 659 & 1,069 \\
\hline Delaware & 36 & 55 & 228 & 399 & 1 & 2 & 264 & 457 \\
\hline District of Columbia & 24 & 4 & 27 & 5 & 0 & 0 & 51 & 9 \\
\hline Florida & 254 & 557 & 5,475 & 11,319 & 0 & 0 & 5,728 & 11,876 \\
\hline Georgia & 712 & 675 & 14,070 & 13,475 & 31 & 25 & 14,812 & 14,175 \\
\hline Hawaii & 30 & 65 & 323 & 1,365 & 34 & 17 & 387 & 1,447 \\
\hline Idaho & 73 & 225 & 3,605 & 16,462 & 207 & 1,160 & 3,886 & 17,847 \\
\hline Illinois & 1,590 & 2,408 & 8,544 & 12,281 & 6,763 & 10,414 & 16,897 & 25,103 \\
\hline Indiana & 1,086 & 1,148 & 7,489 & 7,600 & 22 & 24 & 8,596 & 8,772 \\
\hline lowa & 1,782 & 2,624 & 8,626 & 12,691 & 8,745 & 12,996 & 19,153 & 28,311 \\
\hline Kansas & 582 & 1,112 & 10,256 & 20,962 & 11,642 & 24,738 & 22,481 & 46,812 \\
\hline Kentucky & 605 & 570 & 10,200 & 8,914 & 11 & 11 & 10,816 & 9,496 \\
\hline Louisiana & 476 & 749 & 5,231 & 9,827 & 0 & 0 & 5,707 & 10,576 \\
\hline Maine & 51 & 235 & 1,143 & 6,271 & 52 & 355 & 1,246 & 6,860 \\
\hline Maryland & 258 & 219 & 1,823 & 1,935 & 32 & 42 & 2,113 & 2,196 \\
\hline Massachusetts & 131 & 150 & 932 & 1,499 & 172 & 66 & 1,234 & 1,714 \\
\hline Michigan & 449 & 759 & 5,988 & 10,855 & 857 & 1,328 & 7,295 & 12,942 \\
\hline Minnesota & 975 & 1,902 & 6,918 & 16,800 & 8,055 & 16,605 & 15,948 & 35,307 \\
\hline Mississippi & 586 & 891 & 7,356 & 11,048 & 0 & 0 & 7,942 & 11,939 \\
\hline Missouri & 962 & 1,411 & 10,314 & 16,162 & 722 & 1,199 & 11,998 & 18,772 \\
\hline Montana & 29 & 187 & 4,527 & 30,357 & 4,535 & 30,603 & 9,091 & 61,147 \\
\hline Nebraska & 716 & 1,120 & 8,785 & 18,925 & 9,211 & 19,551 & 18,712 & 39,595 \\
\hline Nevada & 13 & 52 & 1,541 & 24,684 & 51 & 796 & 1,605 & 25,532 \\
\hline New Hampshire & 50 & 101 & 710 & 1,686 & 39 & 142 & 799 & 1,929 \\
\hline New Jersey & 654 & 293 & 1,518 & 1,424 & 2 & 2 & 2,174 & 1,719 \\
\hline New Mexico & 14 & 71 & 3,438 & 33,237 & 1,192 & 10,248 & 4,644 & 43,557 \\
\hline New York & 1,364 & 682 & 4,469 & 9,368 & 431 & 938 & 6,263 & 10,988 \\
\hline North Carolina & 581 & 779 & 8,379 & 10,786 & 47 & 47 & 9,007 & 11,612 \\
\hline North Dakota & 387 & 1,249 & 4,513 & 15,505 & 7,364 & 25,340 & 12,264 & 42,094 \\
\hline Ohio & 786 & 934 & 6,776 & 8,257 & 51 & 44 & 7,613 & 9,236 \\
\hline Oklahoma & 130 & 311 & 7,351 & 17,425 & 6,762 & 16,256 & 14,243 & 33,993 \\
\hline Oregon & 60 & 212 & 2,560 & 17,997 & 260 & 1,624 & 2,880 & 19,833 \\
\hline Pennsylvania & 407 & 625 & 5,102 & 8,926 & 68 & 132 & 5,577 & 9,683 \\
\hline Rhode Island & 36 & 21 & 336 & 198 & 5 & 1 & 376 & 220 \\
\hline South Carolina & 209 & 355 & 4,051 & 7,013 & 5 & 8 & 4,265 & 7,376 \\
\hline South Dakota & 360 & 756 & 6,006 & 18,368 & 10,689 & 32,756 & 17,055 & 51,880 \\
\hline Tennessee & 395 & 492 & 7,957 & 9,141 & 41 & 42 & 8,392 & 9,675 \\
\hline Texas & 507 & 1,201 & 24,935 & 68,564 & 10,938 & 26,869 & 36,381 & 96,633 \\
\hline Utah & 21 & 65 & 2,377 & 17,723 & 75 & 635 & 2,473 & 18,423 \\
\hline Vermont & 29 & 52 & 971 & 1,771 & 94 & 177 & 1,094 & 1,999 \\
\hline Virginia & 993 & 430 & 10,383 & 8,250 & 80 & 81 & 11,455 & 8,761 \\
\hline Washington & 94 & 378 & 2,514 & 11,393 & 296 & 1,260 & 2,903 & 13,030 \\
\hline West Virginia & 145 & 144 & 4,239 & 4,811 & 94 & 150 & 4,478 & 5,105 \\
\hline Wisconsin & 502 & 866 & 5,478 & 11,080 & 717 & 1,351 & 6,697 & 13,297 \\
\hline Wyoming & 3 & 24 & 2,051 & 22,089 & 1,890 & 20,442 & 3,944 & 42,555 \\
\hline U.S. Total & 20,292 & 30,209 & 265,028 & 717,249 & 94,933 & 273,361 & 380,253 & $1,020,819$ \\
\hline
\end{tabular}




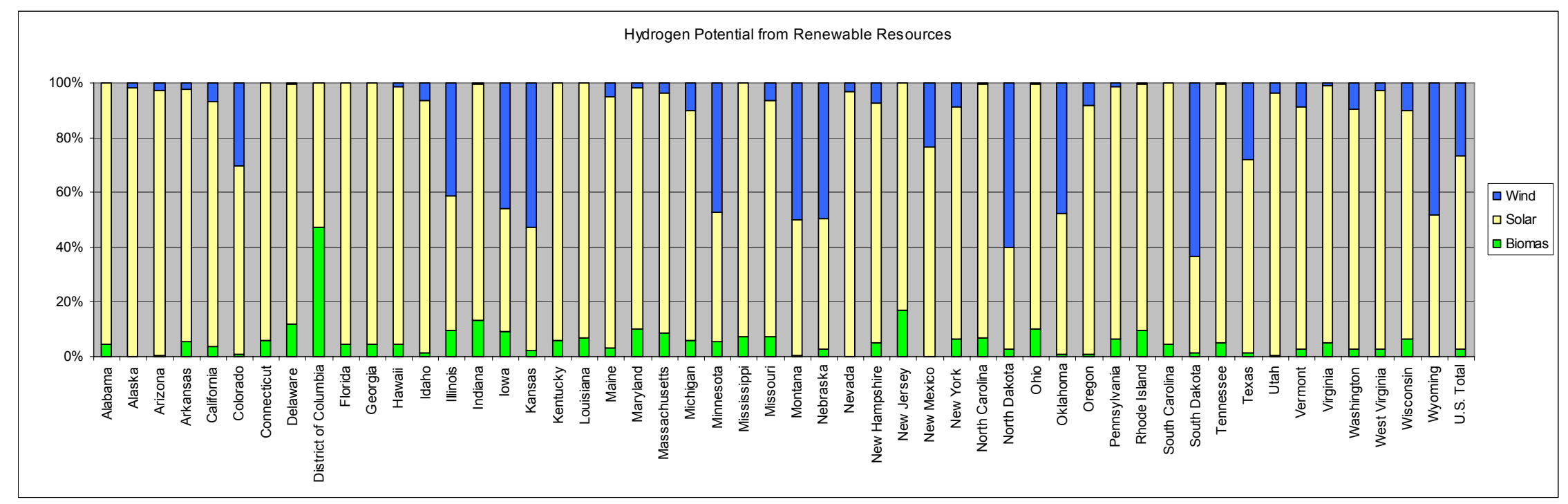

Figure 16. Hydrogen production potential from renewable resources 


\section{Renewable Hydrogen as a Transportation Fuel}

A study was conducted to estimate the amount of gasoline consumption that could potentially be displaced by renewable hydrogen in each county. Gasoline consumption data for 2002 were obtained from the Federal Highway Administration ${ }^{7}$ to generate the map of Figure 17. The results of this analysis show that the most populated counties cannot produce enough hydrogen from renewable resources to completely displace their high gasoline consumption. However, they could, in most cases, rely on hydrogen from surrounding counties (Figure 18). Renewable hydrogen in these counties (urban areas) could displace less than $50 \%$ of their gasoline consumption.

In contrast, counties in the Rocky Mountain-Great Plains region, because of their relatively low gasoline consumption and high amounts of renewable resources, have the potential to displace more than 40-50 times their current gasoline demand. At the state level, only Connecticut, the District of Columbia, Maryland, Massachusetts, New Jersey, and Rhode Island lack the resources to completely displace gasoline with renewably generated hydrogen (Figure 19). Table 3 presents the accompanying values.

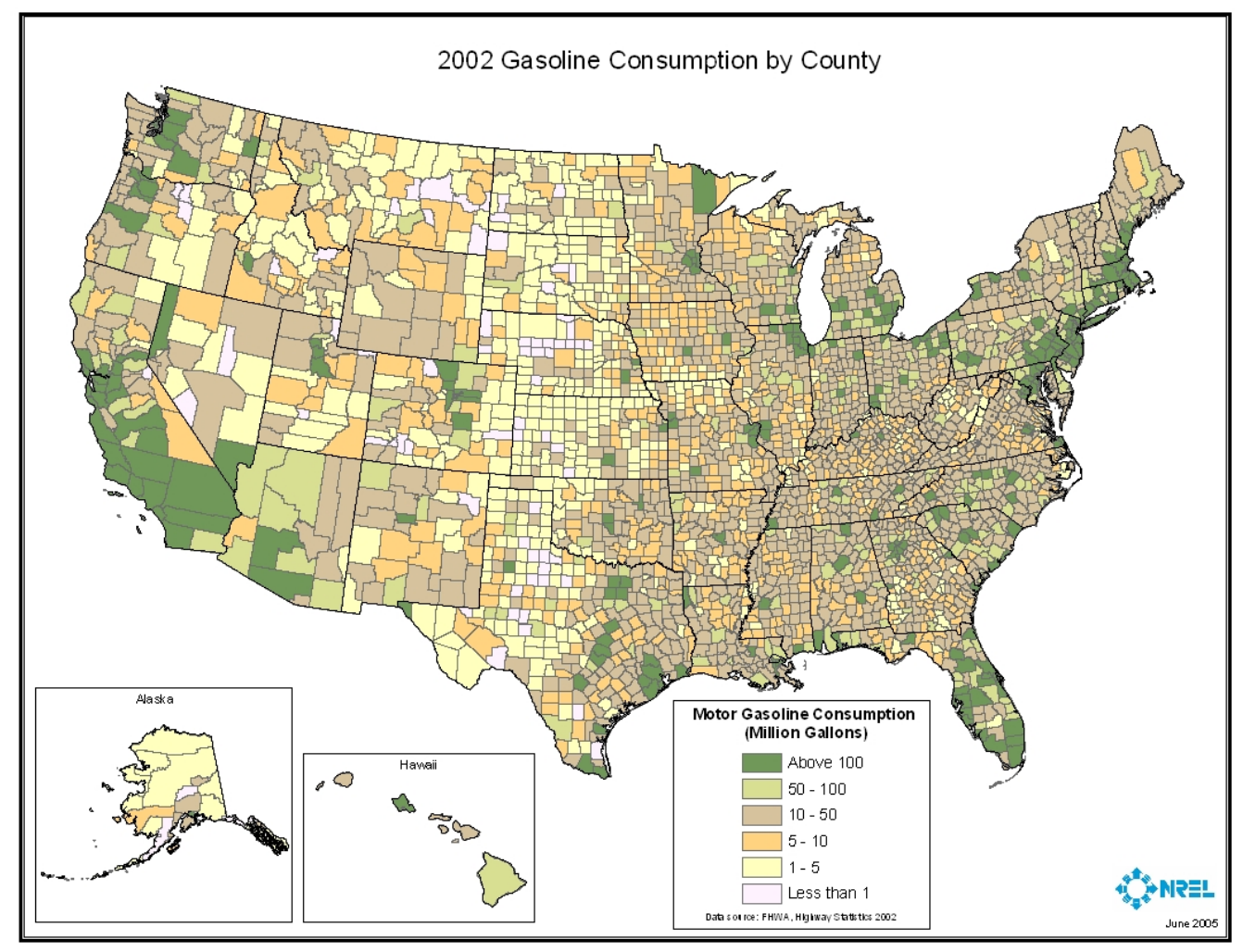

Figure 17. U.S. gasoline consumption by county, 2002

\footnotetext{
${ }^{7}$ U.S. Department of Transportation, Federal Highway Administration, Highway Statistics 2002, http://www.fhwa.dot.gov/policy/ohim/hs02/
} 


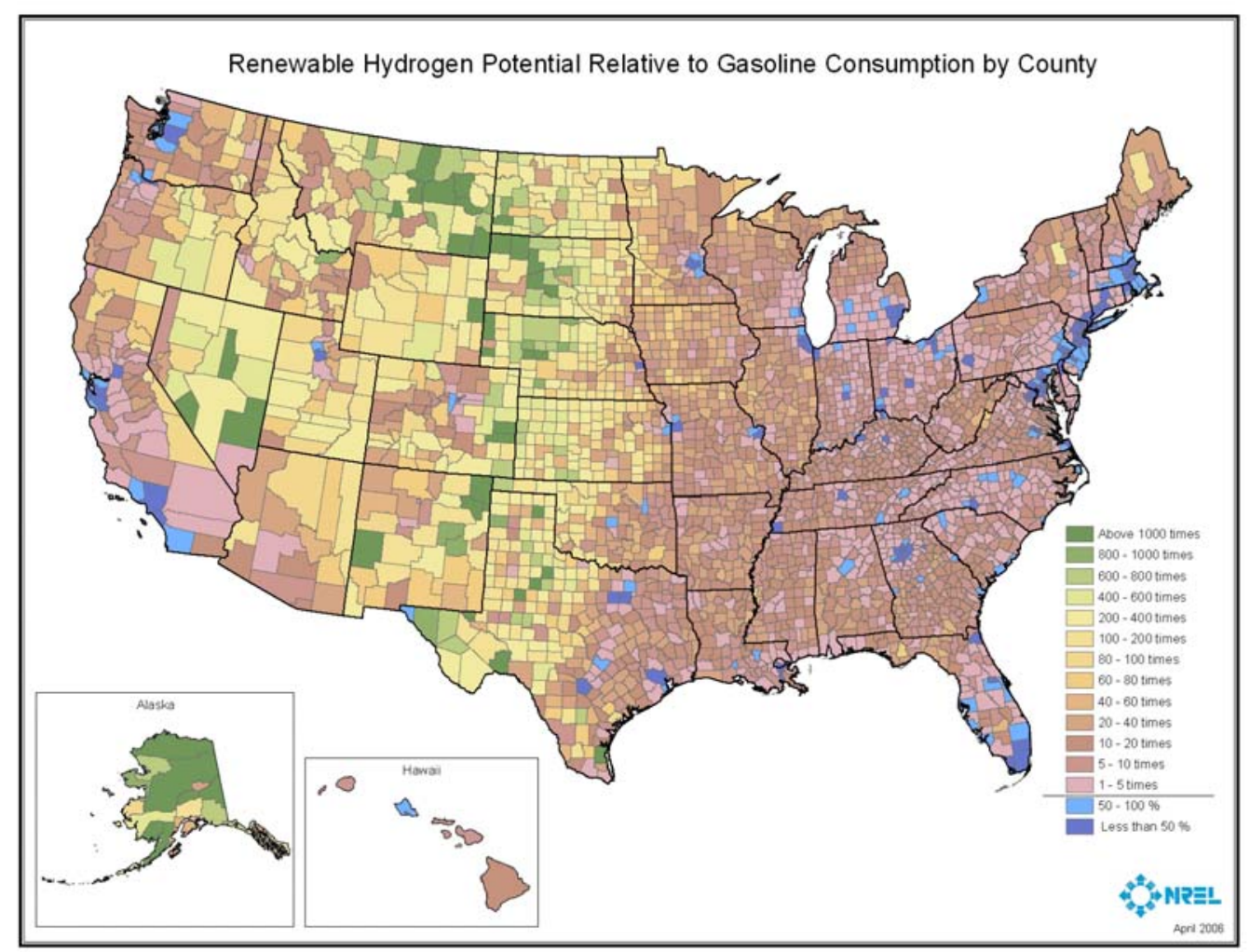

Figure 18. Renewable hydrogen production potential relative to gasoline consumption, by county 


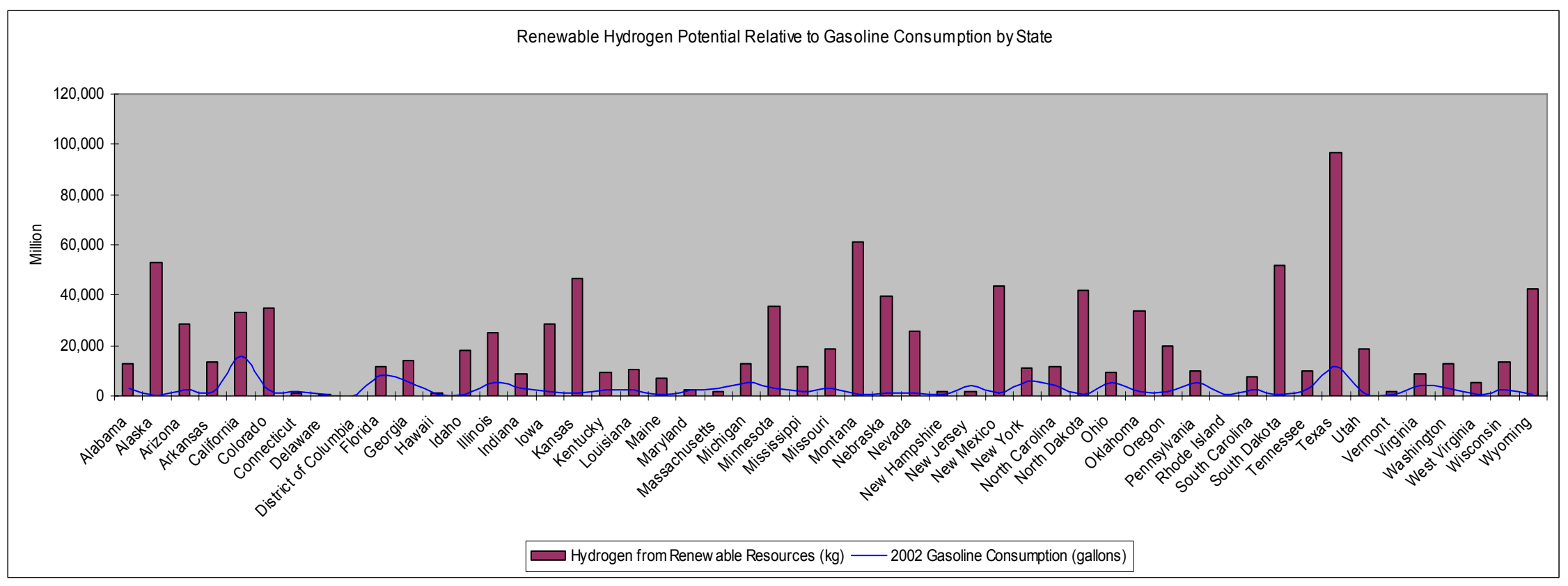

Figure 19. Renewable hydrogen production potential relative to gasoline consumption, by state 
Table 3. Renewable Hydrogen Production Potential Relative to Gasoline Consumption and Population

$\quad$ State
Alabama
Alaska
Arizona
Arkansas
California
Colorado
Connecticut
Delaware
District of Columbia
Florida
Georgia
Hawaii
Idaho
Illinois
Indiana
lowa
Kansas
Kentucky
Louisiana
Maine
Maryland
Massachusetts
Michigan
Minnesota
Mississippi
Missouri
Montana
Nebraska
Nevada
New Hampshire
New Jersey
New Mexico
New York
North Carolina
North Dakota
Ohio
Oklahoma
Oregon
Pennsylvania
Rhode Island
South Carolina
South Dakota
Tennessee
Texas
Utah
Vermont
Virginia
Washington
West Virginia
Wisconsin
Wyoming
U.S. Total

Hydrogen from Renewable Resources (million kg)

12,602

52,828

28,302

13,139

33,401

34,994

1,069

457

9

11,876

14,175

1,447

17,847

25,103

8,772

28,311

46,812

9,496

10,576

6,860

2,196

1,714

12,942

35,307

11,939

18,772

61,147

39,595

25,532

1,929

1,719

43,557

10,988

11,612

42,094

9,236

33,993

19,833

9,683

220

7,376

51,880

9,675

96,633

18,423

1,999

8,761

13,030

5,105

13,297

42,555
2002 Gasoline Consumption (million gallons)

2,624

260

2,605

1,467

15,699

2,106

1,590

426

167

7,999

4,961

446

668

5,212

3,188

1,617

1,230

2,158

2,349

720

2,568

2,851

5,170

2,727

1,632

3,164

509

889

1,004

715

4,095

952

5,808

4,315

366

5,295

1,796

1,572

5,241

404

2,346

456

3,090

11,410

1,038

346

3,888

2,760

820

2,591

354

137,664
2000 Population (thousand people)

4,447

627

5,131

33,872

4,301

3,406

784

572

15,982

8,186

1,212

1,294

12,419

6,080

2,926

2,688

4,042

4,469

1,275

5,296

6,349

9,938

4,919

2,845

5,595

902

1,711

1,998

1,236

8,414

1,819

18,976

8,049

642

11,353

3,451

3,421

12,281

1,048

4,012

755

5,689

20,852

2,233

609

7,079

5,894

1,808

5,364

494

281,422 


\section{Conclusions}

About 1 billion metric tons of hydrogen could be produced from wind, solar, and biomass resources annually in the United States. The Great Plains emerge as the area with the highest potential for producing hydrogen from these key renewable resources. Each county in this region could produce more than 30 million $\mathrm{kg}$ of hydrogen per year (greater than 150,000 $\mathrm{kg} / \mathrm{km}^{2}$ ). Moreover, because they have fewer environmental and land-use exclusions and low populations, most counties in the Great Plains have the highest hydrogen production potential per capita, more than $100,000 \mathrm{~kg}$ of hydrogen per person. Results are shown in terms of kilograms of hydrogen, because $1 \mathrm{~kg}$ of hydrogen contains approximately the same energy as 1 gallon of gasoline, both on a lower heating value basis.

Finally, this research suggests that renewable hydrogen has the potential to displace gasoline consumption in most states. However, the infrastructure needed to enable the widespread use of hydrogen as a transportation fuel is not available, resources are located outside demand areas, and the methods of producing hydrogen from renewable resources face many technical and economic hurdles. All these barriers must be overcome if hydrogen is to fuel a sustainable transportation economy. 


\section{References}

Elliott, D.L., Holliday, C.G., Barchet, W.R., Foote, H.P., Sandusky, W.F. 1987. Wind Energy Resource Atlas of the United States. DOE/CH100093-4. Produced by the National Renewable Energy Laboratory for the U.S. Department of Energy, Washington, DC.

George, R., Maxwell, E. 1999. "High-Resolution Maps of Solar Collector Performance Using A Climatological Solar Radiation Model." Proceedings of the 1999 Annual Conference, American Solar Energy Society, Portland, ME.

Heimiller, D.M., Haymes, S.R. 2001. Geographic Information Systems in Support of Wind Energy Activities at NREL. National Renewable Energy Laboratory, Golden, CO.

Hydrogen Analysis (H2A) Project, December 2006:

http://www.hydrogen.energy.gov/h2a analysis.html

Ivy, J. April 2004. Summary of Electrolytic Hydrogen Production. National Renewable Energy Laboratory, Golden, CO.

Levene, J., Mann, M., Margolis, R., Milbrandt, A. 2005. Analysis of Hydrogen Production from Renewable Electricity Sources. National Renewable Energy Laboratory, Golden, CO.

Maxwell, E., George, R., Wilcox, S. “A Climatological Solar Radiation Model.” Proceedings of the 1998 Annual Conference, American Solar Energy Society, Albuquerque, NM.

Milbrandt, A., 2005. A Geographic Perspective on the Current Biomass Resource Availability in the United States. National Renewable Energy Laboratory, Golden, CO.

Milne, T., Elam, C., Evans, R. 2002. Hydrogen from Biomass - State of the Art and Research Challenges. National Renewable Energy Laboratory, Golden, CO.

National Renewable Energy Laboratory, March 2006. Solar data and maps: http://www.nrel.gov/gis/solar.html, Golden, CO.

National Renewable Energy Laboratory, March 2006. Wind data and maps: http://www.nrel.gov/gis/wind.html, Golden, CO.

National Renewable Energy Laboratory, March 2006. Biomass data and maps: http://www.nrel.gov/gis/biomass.html, Golden, CO.

Power Technologies Energy Data Book, December 2005: http://www.nrel.gov/analysis/power_databook/.

Short, W., Blair, N., Heimiller, D. 2005. Modeling the Market Potential of Hydrogen from Wind and Competing Sources, National Renewable Energy Laboratory, Golden, CO. 


\section{REPORT DOCUMENTATION PAGE}

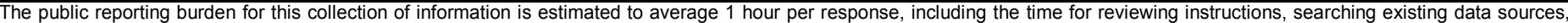

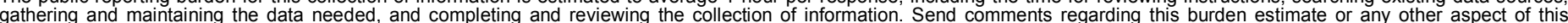

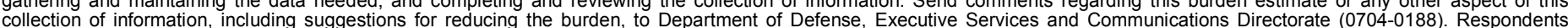

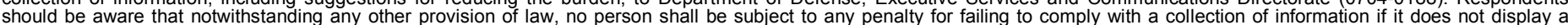

should be aware that notwithstandin

PLEASE DO NOT RETURN YOUR FORM TO THE ABOVE ORGANIZATION.

\begin{tabular}{l|l|l|} 
1. REPORT DATE $(D D-M M-Y Y Y Y)$ & 2. REPORT TYPE & 3. DATES COVERED (FrOm - TO)
\end{tabular}

February 2007

Technical report

4. TITLE AND SUBTITLE

Potential for Hydrogen Production from Key Renewable Resources in the United States

A. Milbrandt and M. Mann 5a. CONTRACT NUMBER

DE-AC36-99-G010337

5b. GRANT NUMBER

5c. PROGRAM ELEMENT NUMBER

5d. PROJECT NUMBER

NREL/SR-640-41134

5e. TASK NUMBER

$\mathrm{H} 278.2100$

5f. WORK UNIT NUMBER

7. PERFORMING ORGANIZATION NAME(S) AND ADDRESS(ES)

National Renewable Energy Laboratory

1617 Cole Blvd.

Golden, CO 80401-3393

9. SPONSORING/MONITORING AGENCY NAME(S) AND ADDRESS(ES)

National Renewable Energy Laboratory

1617 Cole Blvd.

Golden, CO 80401-3393

12. DISTRIBUTION AVAILABILITY STATEMENT

National Technical Information Service

U.S. Department of Commerce

5285 Port Royal Road

Springfield, VA 22161

13. SUPPLEMENTARY NOTES

NREL Technical Monitor:

14. ABSTRACT (Maximum 200 Words)

This study was conducted to estimate the potential for hydrogen production from key renewable resources (onshore wind, solar photovoltaic, and biomass) by county in the United States and to create maps that allow the reader to easily visualize the results. To accomplish this objective, the authors analyzed renewable resource data both statistically and graphically utilizing a state-of-the-art Geographic Information System (GIS), a computer-based information system used to create and visualize geographic information.

15. SUBJECT TERMS

hydrogen; potential; renewable resources; United States; resource map; GIS; National Renewable Energy Laboratory; NREL

\begin{tabular}{l}
\hline 16. SECURITY CLASSIFICATION OF: \\
\begin{tabular}{l|l|l|}
\hline a. REPORT & b. ABSTRACT & c. THIS PAGE \\
Unclassified & Unclassified & Unclassified \\
& & \\
\end{tabular} \\
\hline
\end{tabular}

\begin{tabular}{l|l} 
17. LIMITATION \\
OF ABSTRACT \\
UL
\end{tabular}

19a. NAME OF RESPONSIBLE PERSON

19b. TELEPHONE NUMBER (Include area code) 